\title{
Non-specific, specific and obscured perception verbs in Baltic languages
}

\author{
BERNHARD WÄLCHLI \\ Stockholm University
}

Opportunistic perception verbs ('see', 'hear', as opposed to explorative perception verbs, 'look', 'listen') express the opportunity for perception and are conditionoriented (exposure, i.e. the perceiver's exposure to a percept), not participantoriented, in their aspectual structure. The Baltic languages, as other languages in Central, East, and Northern Europe, have specific perception verbs, which are a subtype of opportunistic perception verbs, for the expression of restricted exposure. The lexical character of specificity in Baltic-unlike Russian where it is integrated into a rigid grammatical aspect system-is more favorable for uncovering the underlying semantic factors of specificity, which differ across perceptual systems. Restrictedness of exposure is a scale rather than a dichotomy, and cross-linguistic comparison in parallel texts reveals that specificity is a scale with much variation as to where the borderline between specific and non-specific perception verbs is drawn in the languages of the area. Obscured perception verbs, which emphasize difficulty in discrimination, are another set of conditionoriented perception verbs in Baltic and Russian and are closely related to specific verbs synchronically and diachronically.

This paper describes non-specific, specific, and obscured perception verbs in the Baltic languages and attempts to capture their variability within six dimensions (morphology, area, diachrony, specificity, modality, obscured verbs). A precondition for this endeavor is a critique of earlier approaches to the semantics of perception verbs. Nine major biases are identified (nominalism, physiology, discrete features, vision, paradigmatic modelling, aspectual event types, dual nature models, participant orientation, and viewing activity as control). In developing an alternative, the approach greatly profits from Gibson's ecological psychology and Rock's theory of indirect perception.

Keywords: perception verbs, Lithuanian, Latvian, lexical typology, aspect, semantic maps, parallel texts, prefixation, ecological psychology, nominalism

\section{Introduction}

The Baltic languages have lexical pairs of perception verbs as shown in Table 1 similar to Russian videt' 'see (imperfective)' and uvidet' 'see (perfective)', but unlike Russian these pairs are not integrated into a system of grammatical aspect. Here I use the terms non-specific and specific perception verbs for covering both non-grammatical (Baltic) and grammatical (Russian) verb pairs. 
Table 1. Specific and non-specific perception verbs in Lithuanian and Latvian

\begin{tabular}{|c|c|c|c|c|}
\hline & \multicolumn{2}{|l|}{ Lithuanian } & \multicolumn{2}{|l|}{ Latvian } \\
\hline & SPEC & NSPEC & SPEC & NSPEC \\
\hline 'see' & pa-matyti, ǐ̌-vysti & matyti & ie-raudzìt & redzèt \\
\hline 'hear' & $i \check{\text { šgirsti }}$ & girdèti & iz-dzirst (iz-dzirdēt) & dzirdēt \\
\hline 'feel, taste' & pa-justi & jausti (justi) & sa-just & just \\
\hline 'smell' & už-uosti, su-uosti & uosti & sa-ost & ost \\
\hline
\end{tabular}

All specific verbs in Table 1 have prefixes, but different ones for different perceptual systems. Some specific verbs further have $n / s t$-present stems which express uncontrolled change-of-state (Arkadiev 2013, 66): Lithuanian -girs-ti, present -gir-st- $a$ (with st-present stem extension), past -gird-o 'hear[SPEC]', jus-ti, present $j u<n>t-a$ (with $n$-infix in the present stem), past jut-o 'feel[spec]', and -vysti, present - vy-st-a (st-present), past -vyd-o. Latvian iz-dzirst and iz-dzirdēt are not two distinct verbs, but in some grammatical categories, forms of the st-verb iz-dzirst are more likely to be retained than in other grammatical categories.

(Non-)specific perception verbs are also found in other languages of Central, East and Northern Europe, including Hungarian, Modern Georgian, Ossetic, and Swedish. In most of these languages specific verbs are prefixed and specificity is connected to the areal phenomenon of prefixal perfectivization which has been explored in much detail by Arkadiev $(2014,2015) .{ }^{1}$ However, specificity cannot be equated with prefixation. In Swedish specific 'see' and 'hear' are formed with an auxiliary (få se [get see], få syn på [get sight on] 'see[sPEc]', få höra [get hear] 'hear[sPEc]') and in Bulgarian the non-specific verb is derived by suffixation (vidja 'see[PFV]', viždam 'see[IPFV]'). ${ }^{2}$

\footnotetext{
${ }^{1}$ It is important to note that the prefixes are different across different languages and that attempts to draw far-reaching conclusions from the choice of a particular prefix in a particular language, such as Nesset (2010) for Russian $u$-, are doomed to failure as soon as a cross-linguistic perspective is adopted.

${ }^{2}$ Not all prefixed perception verbs are specific. In Lithuanian there is a prefixed verb existing only in the negative neprigirdeti 'to be hard of hearing, not be able to hear well (any more)' for non-specific ability.
} 
Example (1) illustrates the Lithuanian pair girdeti 'hear[NSPEC]' and išgirsti 'hear[SPEC]'. Here and elsewhere in this paper I use examples from fiction by selected authors from the 19th and 20th centuries.

(1) Lithuanian: non-specific and specific 'hear' (J. Aputis, Prieš lapu kritima 24)

[...]o ten Benutis girdi aimanuojant

and there Benutis.NOM.SG hear[NSPEC].PRS.3 wail.PRS.PA

moteriškę: - Dievuliau, dar viena... Išgirdus

woman.ACC.sG God.DIM.voc still one.ACC.sG hear [SPEC].PST.PA

tuos žodžius [...]

that.ACC.PL word.ACC.PL

'and there Benutis hears a woman wailing: 'My God, another one...' Having heard those words...'

While verb pairs in particular languages constitute dichotomies, I will argue in this paper that the underlying semantic distinction is a continuum, which can be detected only if several languages with different borderlines between specific and non-specific are compared. The semantic nature of the distinction cannot be determined with certainty from considering a single example in one language; yet examples from original texts are an important heuristic tool for uncovering and discussing potential factors. Many factors might possibly play a role, including (i) grammatical form, (ii) lexical aspect, (iii) some kind of psychological difference, (iv) exposure, (v) temporal definiteness or totality, and (vi) difficulty, where (ii-vi) are all semantic.

What we can say right away is that the Lithuanian distinction is not strictly grammatical. Unlike Russian, where grammatical form (i) plays an important role and, for instance, present tense in non-future meaning is incompatible with perfective aspect, Lithuanian has no such constraints. Historical present as in (1) is compatible with both non-specific and specific verbs. For understanding the semantics of specificity it is thus more profitable to look at the Baltic languages where lexical semantic distinctions in the field of perception are manifest in a purer form, unaffected by a rigid grammatical category.

Applying Vendler's (1967) lexical aspect theory, (ii) would mean that girdi [NSPEC] is a state and išgirdus [NSPEC] is an achievement (transition to the state of hearing). For (1) this solution seems entirely artificial. However, the two verbs in (1) differ in their level of cognitive processing 
(iii). The psychologist Irvin Rock distinguishes between lower-level perception (here the hearing of sound) and higher-level perception (here the hearing of speech), which can feed into each other in a perception chain (Rock 1997, 10). Another psychologist, James J. Gibson, has emphasized the importance of the environment in perception, where exposure (of the percept to the perceiver) is a crucial factor. While for hearing that somebody is wailing, exposure can be viewed as extended over time in (1), exposure is more restricted for understanding what is said. Thus, specificity can be viewed as uniqueness of opportunity (iv). Restriction of exposure can also be interpreted in terms of temporal definiteness (assignment to a unique point in time) or totality (single countable event) (v), notions which figure prominently in Dickey's (2000) approach to Slavic aspect. In (1), the same sound reflects a sequence of not clearly separated opportunities to hear wailing, but only one opportunity for hearing what the woman is saying.

Factors (iii)-(v) all lend themselves all to a common interpretation: more specific perception means more restricted exposure to the percept. Unlike the Vendlerian transition-to-a-state analysis, restricted exposure is not participant-oriented, but condition-oriented. I will argue throughout this paper that conditions such as exposure and difficulty are crucial for understanding the semantics of perception verbs.

Conditions making perception effortless or difficult, (vi), are a further important factor. The Baltic languages and Russian have what I call here obscured perception verbs for seeing and hearing with difficulty (Table 2). (English uses make out for both obscured seeing and obscured hearing.) Obscured perception verbs are very tightly connected to specific perception verbs. Russian obscured verbs are perfectiva tantum (do not have imperfective forms). The Lithuanian obscured verb for 'hear' is the same as specific 'hear'. Note also that obscured verbs in Table 2 are all prefixed.

Table 2. Obscured perception verbs in Baltic and Russian

\begin{tabular}{l|l|l|l}
\hline & Lithuanian & Latvian & Russian \\
\hline 'see' & i-žiūrèti, ì-žvelgti & sa-redzēt, sa-skatït & raz-gljadet' \\
'hear' & iš-girsti & sa-dzirdēt, sa-klausìt & ras-slyšat'
\end{tabular}


Specific and obscured 'see' are exemplified in (2) from Latgalian. This example also illustrates the historical present context (where Russian cannot use perfective verbs). The verbs in Latgalian are the same as in Latvian except for phonological differences (Latgalian iraudzeit, Latvian ieraudzit 'see[SPEC]'). However, Latgalian is more inclined to use specific verbs than Latvian. In Latvian, in particular, the use of the specific verb is restricted if there is no explicit object as in (2), which would make the use of the specific verb odd in the Latvian equivalent to (2).

(2) Latgalian: specific 'see'

(J. Pūrmalīts/Jezups Lelis in Kursīte \& Stafecka 2003, 224)

Es panamu tū bulkas gobolu $i$

I take.PRs.1sg that.ACc.sG roll.GEN.SG piece.ACC. SG and

iraugu - nazkaids papeirs tam

see [SPEC].PRS.1sG some.NOM.SG paper.NOM.SG that.DAT.SG

pïlipis. Vèl vīnā styurì var

attach.PST.PA.NOM.SG.M still one.LOC.SG corner.LOC.SG can.PRS.3

saredzēt taidu kai pīcdasmytū numeri.

see [oвSc].INF such.ACC.SG as fiftieth.ACC.SG.DEF number.ACC.SG

'I take this piece of bread and see-some kind of paper is attached to it. In one corner you can still make out something like the number fifty.'

For smell, Lithuanian, Latvian and Russian lack special obscured verbs. In fact, Latvian uses the same prefix sa- 'together' for specific 'smell', illustrated in (3), which also recurs in obscured 'see' and 'hear'. This provokes questions about the relationship between smell and obscured perception. As we will see in Section 6.2, specific 'smell' is more extended in Latvian than specific 'see', which demonstrates that it is not sufficient to investigate specificity in one perceptual system.

(3) Latvian: specific 'smell' (R. Blaumanis, Dancis pa trim, www.korpuss.lv/klasika/Senie/RBl/RBl0106.htm)

[“Tad iesim drusku pastaigāties,” puisis runāja, galvu vinai tuvu pieliekdams klāt. Viṇš koștāja egles zariñu,]

bet Ilze

tomèr saoda,

ka viňs

but Ilze.NOM.sg still smell[SPEC].PST.3 that 3.NOM.SG.M

bij dzēris.

be.PST.3 drink.PST.PA.NOM.SG.M 
'["Then let's go for a little walk", the young man said, approaching her closely with his head. He had chewed a spruce twig,] but Ilze all the same smelled that he had been drinking.'

In this paper I term 'see' and 'hear' opportunistic perception verbs as opposed to explorative perception verbs, such as 'look' and 'listen'. I am, of course, aware that these two types are usually termed 'experience' vs. 'activity' (Viberg 1984, 2001) or 'cognitive' vs. 'active' (Rogers 1971) in the literature. However, studying what psychologists have to say on perception has convinced me that 'see' and 'hear' cannot be considered strictly stative. (According to Gibson 1979 perception is active information pickup; according to Rock 1983 it is a thought-like cognitive process.) Explorative verbs are like 'seek'-and many languages have verbs with a look-seek polysemy such as English 'look' for-and opportunistic verbs are like 'find'-and many languages have a see-find polysemy (for instance Swahili ona 'see, find'). I will not consider the question here whether the notion of specificity can be applied also to explorative perception, even though Russian explorative perception verbs, of course, also form aspectual pairs and even though prefixation is frequent even in Baltic explorative perception verbs. The semantic nature of prefixation in Baltic explorative perception verbs deserves a separate study.

However, explorative verbs cannot be completely disregarded, since some specific (and obscured) verbs with prefixes have explorative bases. For instance, Latvian ie-raudzit [in-watch/look] 'see[sPEc]' has the base raudzit 'watch, look'. The Lithuanian obscured 'see' verbs ị-žiürèti, į-žvelgti [in-look] 'see[oвsc]' have more or less the same makeup as Latvian ieraudzit 'see[sPEC]'. This raises the question as to whether specific and obscured opportunistic perception verbs are in fact accomplishments, i.e. resultative explorative verbs (the result of looking/listening) or-which would be a weaker claim-whether they may at least originate from resultative explorative verbs diachronically.

In fact, the use of explorative and specific opportunistic verbs in sequence ('looked and saw') as in (4) from Latvian speaks in favor of such a resultative interpretation. Seeing usually implies exposure and exposure is beyond control. However, the example also demonstrates the importance of attention which is active and controllable. Note also that the example demonstrates that specific perception verbs need not be punctual, as the metonymic construal headscarf, jacket, apron and skirt emphasizes the gradual coming into sight of the person observed. 
(4) Latvian (R. Blaumanis, Salna Pavasarī, www.korpuss.lv/klasika/Senie/RBl/RBla118.htm)

[Pēdigi viņš atkal pacēla galvu, atspieda to rokā un]

skatijās uz kalnu, aiz kura mājas

look.PST.3.RFL to hill.ACc.sG behind which.GEN.sG house.GEN.SG skurstena gals bija

chimney.GEN.SG end.NOM.SG be.PST.3

redzams.

SEe [NSPEC].PRS.PP.NOM.SG.M

[Plāns dūmu stabin̄š rādija, ka brokastis būs kaut kas silts. "Kas to gan nesis uz leju? Viña? Ak debestin,, liec, lai vina nāk un nevis Annule vai vecā Lizze!"]

Un puisis skatijās noñēmies

and boy.NOM.SG look.PST.3.RFL down.take.PST.PA.NOM.SG.M.RFL

uz kalnu un ieraudzïja tur pēc minūtu

to hill.ACC.sG and see[SPEC].PST.3 there after minute.GEN.PL

sešu septinu ilgas gaidǐšanas gaišrozā

six.GEN.PL seven.GEN.PL long.GEN.SG wait.ACN.GEN.SG light.pink

lakatinu, tumšrozā jaku, baltu

kerchief.ACc.sG dark.pink jacket.ACc.sG white.ACc.sG

priekšautu un pelēkus brunčus.

apron.ACc.sG and grey.ACC.PL skirt.ACC.PL

[Viña smaids tapa vēl jautrāks, un]

vina acis pavadija skuk,i no

3.GEN.SG.M eye.NOM.PL accompany.PST.3 girl.ACC.SG from

kalna lejā,

hill.GEN.SG down

[pār plavu un nenovērsās no vinas, kad tā balto aizsaini nolika ievu krūmu ēnā.]

'[Finally, Andrs, lying in the sun after hard work in the field early in the morning, lifted his head, leaned it on his arm and] looked in the direction of the hill, behind which the chimney top of the house was visible. [The thin bar of smoke meant that the breakfast would be warm. "But who will bring it down. She? Heaven, let it be her and not Annule or the old Lize!"] And the lad watched the hill attentively, and after about a six or seven minutes' wait he saw a light pink headscarf, a dark pink jacket, a white apron and a grey skirt. [His smile turned more cheer- 
ful, and] his eyes accompanied the girl down from the hill [across the meadow and did not turn away from her when she put down the bundle in the shadow of the bird cherry bushes.]'

While (4) is evidence for an accomplishment construal in opportunistic perception verbs, such an assumption is at odds with Vendlerian lexical aspect theory. Since also the assumption of gradual semantic distinctions in the linguistic domain of perception is at odds with the most influential theoretical work on perception verbs, Section 2 consists of a critique of fundamental theoretical biases in the literature on perception verbs. Section 3 will apply the method of probabilistic semantic maps built with parallel text data for demonstrating the gradual nature of the opportunistic-explorative distinction in sight and hearing and of the specificity distinction in the 'see' domain. Here I will use a sample that is highly biased on purpose toward Central, East and North European languages, since it is these languages where the lexicalization of specificity is expected. The purpose of massive cross-linguistic comparison here is not to explore how the encoding of perception is reflected across the whole world, but how the encoding of a specificity distinction may differ cross-linguistically. Next, Section 4 is devoted to exemplifying the usefulness of psychological approaches to perception for analysing examples from original texts from Baltic languages (mostly from fiction). Section 5 explores obscured perception verbs in the Baltic languages and Russian. Section 6 discusses how specific perception verbs in the Baltic languages relate to aspect in Slavic languages. Finally, Section 7 sorts the considerable diversity observable in specific and obscured perception verbs in the Baltic languages across space and time into six dimensions of variability and considers to what extent these can be considered to be clines. Section 8 concludes this paper.

\section{Nine biases in the study of perception verbs}

Since I disagree with basic assumptions in the most influential approaches to the study of perception verbs, and, in particular, aspect in perception verbs, a section on biases in earlier research is needed. The nine biases to be discussed here are not independent of each other. The most fundamental one is (i) nominalism. Only (ii) physiology and (iv) vision are restricted to perception, so it might be argued that the other biases are 
more general biases in semantics. However, since this paper focuses on perception verbs, I will address all biases only with respect to the study of perception verbs. The aim of pointing out the biases is to open up space for alternative approaches to the study of perception verbs.

\section{(i) Bias toward nominalism}

Most approaches to the semantics of perception verbs adopt a nominalist perspective. Scholars with a nominalist metaphysical view give primacy to language or other symbolic systems as the sole possible source for general or abstract terms, as opposed to realists or phenomenologists who believe that generalizations also exist in other terms than linguistic or symbolic. To put it very simply, nominalists believe that only by studying language or other symbolic systems can we learn something about the world or at least about how humans conceive of the world. Realists believe that the world can be studied also without making reference to words. Not incidentally, there is a very strong bias toward nominalist approaches in linguistics. Let us briefly consider some important studies of perception verbs with different theoretical backgrounds which all take a strongly nominalist stance.

Gruber (1967) investigates the meaning of English look and see by considering the underlying strings into which they are inserted. He comes to the conclusion that both look and see are motion verbs of some sort because they can be used with directional prepositions as in It is easy to see through this glass. No attempt is made to consider how perception is related to motion beyond similarities in linguistic constructions. Cognitive approaches can suffer as much as generative approaches from localistic views and nominalistic bias. A modern example is Nesset (2010).

Sweetser (1990, ch. 2) uses etymologies as a major source for investigating differences between the sense modalities in order to explain differences in metaphorical extensions of one or another sense modality.

Divjak $(2015,44)$ applies the distributional hypothesis "that the meaning of a word is derived from the linguistic contexts in which it occurs" to perception verbs in Russian. She explores differences in frequency with which Russian perception verbs for different sense modalities occur with various morphological markers and syntactic constructions, and argues that these are sources for building up viable representations of concepts even if sensory experience is lacking (Divjak 2015, 44). 
The nominalist bias entails a strong underrepresentation of references to the psychological literature in studies of perception verbs. The approach adopted here is that the linguistic expression of perception and the phenomenology of perception are unlikely to be entirely irrelevant to each other even though it cannot be taken for granted that all aspects of the phenomenology are relevant for linguistics and vice versa. Nominalism and realism are taken here as two perspectives with neither of them having primacy over the other one. Put differently, sometimes we might be able to learn things about perception verbs from studying first what perception is like. Sometimes we might be able to learn things about perception by studying how perception verbs are used.

\section{(ii) Bias toward physiology}

Linguists often view perception as physical or physiological. Horie (1993, 3) distinguishes between Directly/physically Perceived Events (I heard John singing a song) and Indirectly/mentally Perceived Events (I thought that he was singing a song). Cognitive linguistics emphasizes the notion of embodiment according to which mental and linguistic categories are created on the basis of experience and under constraints imposed by our bodies (see, e.g., Lakoff \& Johnson 1980; Ibarretxe-Antuñano 1999, 18). Sweetser $(1990,28)$ views cognitive uses of perception verbs as instances of a mind-as-body conceptual metaphor.

However, there are alternatives to viewing perception as primarily physiological. Perception can be conceived of as strongly determined by external circumstances (the environment) as in Gibson's (1979) ecological psychology or it can be viewed as cognitive as in Rock's (1997) approach according to which perception is generally indirect and thought-like. (It may be confusing that cognitive linguists do not consider perception to be cognitive, but I am not responsible for this confusion.)

The widespread beliefs that perceiving is experiencing a stimulus and that seeing is seeing light and colors in the retinal picture are further manifestations of the physiological bias.

In textbooks of syntax and semantics we learn that 'see' has the semantic roles experiencer and stimulus (for instance, Van Valin 2001, 29). The concept of stimulus comes originally from physiology where it means energy exciting a reflex response in a nerve cell, and was extended to psychology where it became particularly popular in behaviorism. However, what holds for a nerve cell does not necessarily hold for the whole body 
containing that nerve cell. According to Gibson $(1979,50)$ perception "is not a response to a stimulus, but an act of information pickup". In vision, the receptors in the retina are stimulated, but the pairs of mobile eyes in a head that can turn attached to a body that can move are activated for information pickup.

Cognitive linguistics has empiricist roots. According to Locke's (16901714) influential empiricist theory, our senses can register only properties, such as colors, temperature, or smells, which are 'simple ideas'. The perception of objects requires a combination of simple ideas. Empiricism is the starting point for the belief that all we see is color, all we hear is sound, all we smell is odor, all we taste is sweet, sour, salty and bitter, and all we feel is pressure on skin. However, even though we can talk about perceiving properties, more often we talk about perceiving objects and events. This is pointed out by Viberg (2001, 1295), but his wording clearly reflects the burden of empiricism: "Even if it is possible to use physical perception verbs to report (relatively) pure sensations (I can see a light, I heard a noise), these verbs usually refer to much more complex phenomena which require a great amount of cognitive interpretation." In the ecological approach to perception, events and objects are the basic units of perception rather than, for instance, light or color. Light in its pure form of radiant light cannot be seen (Gibson 1979, 45).

\section{(iii) Bias toward discrete features}

Many approaches, both typological and non-typological, take for granted that meaning can be described in terms of discrete units. This is a consequence of the nominalist approach to semantics, see (i) above. Meanings are assumed to be discrete, as language-specific expressions are. Given the discrete nature of language, a discrete approach to meaning can hardly be avoided whenever semantic analysis is based on any kind of metalanguage (whether or not including semantic decomposition).

According to Viberg $(1984,123)$ the distinction between English look and see is due to the general components activity and experience. Ibarretxe-Antuñano (1999) suggests a large number of properties, along which sense modalities can be classified. For instance, the property $<$ identification $>$ is 'no' for smell, but 'yes' for all other senses because smells are difficult to identify (Ibarretxe-Antuñano 1999, 147). Although informed by psychological research, her approach has the disadvantage shared by all other approaches discussed in this section, that it is strictly 
categorical. Sometimes we can easily identify what we smell, sometimes we cannot identify what we see or hear.

As far as aspect is concerned, it is hardly possible to disagree with aspectologists that events can be stative or non-stative and telic or nontelic. The important question, however, is whether these and other properties are discrete or whether there can be intermediate cases. Almost all aspectologists take for granted that the distinctions are discrete, that there cannot be, for instance, any intermediate case between a state and an achievement.

Categorization is a design feature of language and, in particular, of particular languages. While all languages categorize, different languages draw borders at different places. This is why cross-linguistic research is indispensable in semantic studies because it is the only empirical way to overcome language-specific categorization. However, cross-linguistic research must be done in such a way that discrete semantic distinctions are not adopted a priori in the design of the study. This can be achieved by a cross-linguistic comparison of concrete examples in parallel texts, which is one of the methods pursued in this study (see Section 3).

\section{(iv) Bias toward vision}

Many linguists take for granted that 'see' is representative for all sense modalities, especially when it comes to event structure and aspect. It is very common that visual verbs are the only ones mentioned when perception verbs are discussed, especially in studies on aspect. This holds, for instance, for Tatevosov (2002) and Croft (2012). Sometimes, other sense modalities are mentioned, but the question whether they could behave in different ways does not arise, as in Dowty $(1978,114)$.

There is solid typological evidence that vision is more dominant cross-linguistically than other sense modalities, notably Viberg's (1984) well-known lexicalization and markedness hierarchy: sight $>$ hearing $>$ touch/taste/smell (in its simplest form, Viberg 2001, 1297; see Nakagawa for some modifications of the hierarchy and Evans \& Wilkins 2000 for showing that it only holds within the perception domain, not in the metaphorical extension to the cognitive domain). Further evidence for differences between the sense modalities comes from research on metaphors (Sweetser 1990; Ibarretxe-Antuñano 1999, 18) and from corpus linguistics (Divjak 2015). This paper considers possible differences in aspectual structure (see Section 6.2). 


\section{(v) Bias toward a paradigmatic model of lexical field}

Viberg $(1984,124)$ postulates a "basic paradigm of the verbs of perception" with $5 \times 3$ discrete cells. ${ }^{3}$ The paradigm is structured, on the one hand, by field-specific properties, the five sense modalities sight, hearing, touch, taste, and smell, and, on the other hand, by three different possibilities for how perceiver and percept map onto semantic case roles and grammatical relations: activity (looks, listens) with the perceiver in the semantic role of an agent, experience (sees, hears) with the perceiver in the semantic role of an experiencer, and source- or phenomenon-based (looks happy, sounds sad) with the percept as subject. If there is more than one verb in a cell, it is taken for granted that one verb is basic and the other ones are hyponyms. Since this paradigmatic structure is postulated a priori before the typological investigation is carried out, it cannot be falsified empirically. The implicit assumption is that semantics is as rigid as morphology (where the notion of paradigm comes from) and, unlike morphology, universally rigid.

The paradigmatic model bias is a special case of the discrete-feature bias (iii) in combination with the sight/hearing bias (iv). The diversity of smell verbs (e.g., English stink, reek, sniff, get a whiff) is easily underrated if English smell and corresponding terms in other languages are considered the only base verb for activity, experience and source. The three cells are much less appropriate for smell than for see and hear.

Viberg's model has the disadvantage that it cannot account for intermediate cases between the cells as, for instance, ambulatory vision 'go/ come and see/look' where there is considerable cross-linguistic variation between 'see' and 'look' verbs (see Section 3). It also downplays the diversity of different semantic types of perception verbs. For instance, the obscured perception verbs (see Section 5) cannot easily be localized in the base paradigm.

While Viberg's approach has been proven to be a highly useful heuristic tool for detecting cross-linguistically valid anomalies in the lexicalization of perception verbs, I reject it as a theoretical starting point. The structure of the lexical field of perception verbs cannot be given a priori. It has to be built bottom-up, for instance in a semantic map approach, as attempted for some parts of the field in Section 3.

\footnotetext{
${ }^{3}$ Rogers $(1971,1972)$ and Scovel (1971) make similar distinctions but use different terms.
} 


\section{(vi) Bias toward aspectual event types}

Predicates express events, and events have aspectual properties such as stativity, permanence, activity, telicity and boundedness. Strangely enough, most semanticists adopt an extreme nominalist and discretefeature approach to aspect, which results in postulating that aspectual properties are event types. The most influential approach is the one by the philosopher Zeno Vendler. According to Vendler (1967) all events can be classified into one of four aspectual classes: states, activities (also called processes), accomplishments, and achievements. While this approach classifies events and not verbs, it derives legitimation from the claim that the relationship between verbs and event types is constrained. For instance, see can be a state or an achievement, but not an activity. This is determined on the basis of linguistic tests, such as the progressive test (i.e., with nominalism). Vendler $(1967,115)$ argues that "seeing cannot be a process. What are you doing? can never, in good English, be answered by I am seeing." After deciding that seeing can be both a state and an achievement there is nothing more to say about 'see' for Vendler. "We have no reason to fear that seeing, for example, since it is not always an achievement, might turn out to be an activity after all reviving thereby all the ghosts of epistemology" (Vendler 1967, 120). Other linguists inspired by Vendler do not always posit exactly the same aspectual classes, and the battery of tests has been refined, among others by Dowty (1979).

In this paper, this extreme nominalist and discrete-feature approach is rejected. There is no need to revive anything; all that is necessary is to take into account psychological approaches which have been largely neglected in the study of aspect. This does not mean that all psychological research is equally relevant for our purposes. What is relevant, though, is the psychological study of properties normally associated with aspect. For instance, in seeing there is the experience of a stable world, even though the eye is hardly ever stable due to saccadic eye movements and the prolonged fixing of the eyes on an object or part of an object, "the bringing of its image to the fovea and keeping it there, does not occur in life" (Gibson 1979, 211). Gibson (1966, 47) conceives of the senses as active perceptual systems rather than passive conveyers of mere sensory quality. "One sees the environment not just with the eyes but with the eyes in the head on the shoulders of a body that gets about" (Gibson 1979, 222), i.e. with ambient and ambulatory vision. Rock (1983, 339) argues that per- 
ception is thought-like as it entails reasoning and taking decisions, hence it cannot be entirely stative. For smelling, for instance, the phenomenon of odor adaptation is relevant ("after about fifteen minutes of smelling a particular aroma you effectively no longer perceive the scent"; Herz 2007, 84), which makes smelling potentially less stative than other sense modalities.

\section{(vii) Bias toward dual nature models}

It is widely acknowledged that verbs do not directly correspond to event types. Discrete-feature approaches tend to resolve this by ascribing verbs to pairs of event types. Verbs fall into different types (and the types can be language-specific) according to which pairs of event types they allow for. Following Vendler $(1967,118)$ linguists quite unanimously ascribe to 'see' a dual nature of state and achievement. ${ }^{4}$ As Croft (2012, 38, 54) puts it, predicates such as know, see, or remember are inceptive states with a state (5a) and an achievement (5b) construal in different tense-aspect constructions-in English simple present in (5a) and simple past in (5b) without any morphological derivation.

(5a) I see Mount Tamalpais.

(5b) I reached the crest of the hill and saw Mount Tamalpais.

The two construals have the same aspectual contour, but for (5a) the state 'seen' is profiled (non-dashed line in Figure 1) whereas (5b) profiles the transition.

Figure 1. State and achievement profiling of English see according to Croft $(2012,55)$

a) seen

not seen

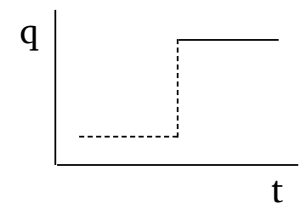

b) seen

not seen

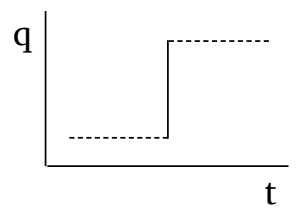

\footnotetext{
${ }^{4}$ Vendler $(1967,113)$ calls the achievement use of 'see' the 'spotting' sense of seeing, which "connotes a unique and indivisible time instant" (Vendler 1967, 114). However, as pointed out by Faber \& Pérez $(1997,67)$ spot also has other semantic features and they define it as "to notice sth momentarily as a result of attending to it. $<+$ intention, + difficulty $>$ ".
} 
In a language with imperfective-perfective verb pairs such as Russian, this entails according to Breu $(1980,208)$ ingressive lexical pairs such as videt'/uvidet' 'see (IPFV/PFV)' and znat'/uznat' 'know (IPFV/PFV)' without any distinction in lexical meaning. In Breu's ILA -model they are called ISTA-verbs (inceptive-stative) (Breu 1998, 60). As Croft $(2012,120)$ puts it, in Russian many perfectives of verbs of perception and cognition profile the inceptive phase, unlike imperfectives. According to Tatevosov (2002, 376) the actional characteristic of a verb (or actional class) can be viewed as a set of aspectual meanings in different tense-aspect forms. In this typology, Russian uvidet'/videt' is strong inceptive stative $<$ \{entry into a state $\}_{\text {perfective, }}$ \{state $\}_{\text {imperfective }}>$ whereas English see is weak inceptive stative $<\{\text { entry into a state, state }\}_{\text {past }}$, $\{\text { state }\}_{\text {present }}>$. This means, I saw Mount Tamalpais also has a stative reading whereas the Russian perfective has not.

All these approaches have difficulties in accounting for the fact that the difference between specific and non-specific 'see' (reflected by aspect in Russian) is not made in the same way across different languages (see Section 3). Put differently, while grammatical distinctions (imperfective vs. perfective) tend to be categorical in particular languages, the borderline is not drawn in the same way in different languages, which speaks against a discrete semantic distinction between specific 'see' and nonspecific 'see'.

Furthermore, also uses of 'see' or 'hear' with explicit inceptive phasal verbs such as (6) from Latvian are rare and rather support activity interpretations for the lexical verb 'see' (akin to Croft's 2012, 61 directed activity, since it is gradual).

(6) Latvian: scalar interpretation of 'see' with an inceptive phasal verb (https://ec.europa.eu/eures/main.jsp?lang $=$ lv\&acro $=\& c$ atId $=9517 \&$ myCatId $=951$...ews\&function $=$ newsOnPortal\&la ngChanged $=$ true)

[Veicot šo darbu, ]

es sāku redzèt pasauli pavisam

I.NOM begin.PST.1sG see[NSPEC].INF world.ACC.sG entirely savādāk.

differently.COMP.ADV

'[Doing this work, ] I started seeing the world in an entirely different way.' 
What also speaks against interpreting all instances of perception verbs as inceptive states is the parallelism to 'read', which is a verb for higherlevel visual information pickup in much the same manner as 'hear' is for auditory information pickup of language. 'See', 'hear' and 'read' can be constructed entirely in parallel, and is it then justified to interpret 'read' as activity and accomplishment and 'see' and 'hear' as states and achievements in examples such as (7)?

(7) Lithuanian: parallelism of 'read', 'hear' and 'see' (pazintys.draugas.lt/narys.cfm?narys $=384885$ ) Viska galiu žiūrèti ir skaityti, bet all.ACc can.PRs.1sG look.INF and read.INF but sunkiau viska (sic!) $k q \quad$ pamatei, difficult.comP.ADV all.ACC what.ACC see [SPEC].PST.2sG perskaitei ar išgirdai suprasti... through.read.PST.2sG or hear [SPEC].PST.2sG understand.INF 'I can watch and read all kinds of things, but it is more difficult to understand all that I have seen, read and heard...'

The dual nature theory predicts that 'see' is never an activity or an accomplishment. However 'see' is sometimes used in the sense of 'follow', which is an activity (see Section 4). In Section 1 I have raised the question whether Latvian specific 'see' might derive from resultative 'look'. A typological parallel is Mandarin Chinese where 'see' is expressed by the resultative 'look-perceive'. Mandarin Chinese has the verb roots tian' 'listen' and $\mathrm{kan}^{4}$ 'look, read' (also perception ability). Opportunistic 'see' and 'hear', however, are derived from 'look' and 'listen' in resultative compounds: kan $^{4}$-jian( ${ }^{4}$ ) [look-perceive] and ting $^{1}$-jian( ${ }^{4}$ ) [listen-perceive] 'hear' (see also Viberg 1983, 68). These can be used in a conative sense, which suggests that they are accomplishments rather than achievements or states in Vendler's terms:

(8) Mandarin: 'see/hear' = 'look/hear-perceive' (Mark 8:18)

$n i^{3} m e n y^{3}$ yan ${ }^{3} j i n g \quad \mathrm{kan}^{4} \mathrm{bu}^{2}$ jian $^{4} \quad \mathrm{ma}$,

you.PL have eye watch not perceive $Q$

you er $^{3}$ duo, ting ${ }^{1} \mathrm{bu}^{2}$ jian $^{4} \quad \mathrm{ma}$

have ear listen not perceive $Q$

'Although you have eyes, do you not see? And although you have ears, do you not hear?' 
In the case of Baltic specific 'hear' (Lithuanian išgirsti, Latvian izdzirdēt), it is not at all clear whether it is rather inceptive or rather terminative. Unlike i-, ie- 'in', the prefix iš-, iz- 'out' is usually terminative (e.g., išgerti 'drink up'). However, even more relevant is that the prefix pa- 'a little', which usually has a delimitative function (paskatities 'watch a little'), can occur as well: Latvian padzirdett/padzirst 'hear superficially, indirectly, as a rumour'. ${ }^{5}$ Hearing, especially hearing speech, differs from seeing in that the source is often unreliable for information pickup or only provides indirect or partial evidence. In (9) Tsar Aleksey does not wait for direct evidence that the Swedish army is approaching. Indirect evidence is sufficient for the decision to terminate information pickup and to take action.

(9) Latvian: delimitative 'hear' (http://www.diena.lv/arhivs/cara-alekseja-neizdeviessapnis-11060390)

Padzirdis, ka Rigai hear [DELIM].PST.PA.NOM.sG.M that Riga.DAT.SG tuvojas zviedru karaspēks, approach.PST.3.RFL Swede.GEN.PL army.NOM.SG [viňš 5.oktobra naktī klusām pārtraucis aplenkumu un Rīgu atstājis.] 'Hearing that the Swedish army was approaching Riga, he [Tsar Aleksey] quietly interrupted the siege on 5 October at night and left Riga.'

To summarize, there are many problems for the inceptive-state theory of 'see' and 'hear'. Cross-linguistic evidence speaks for a continuum between specific and non-specific uses of 'see', the inceptive nature of specific 'see' and 'hear' is in many cases doubtful, and in some cases there is counter-evidence against an inceptive interpretation. Furthermore, 'see' can be sometimes construed as activity or accomplishment, i.e., is not restricted to state and achievement.

\section{(viii) Bias toward participant orientation}

Vendlerian aspectual theory describes aspect in terms of aspectual contour connected to participants. This becomes most manifest in Croft's

\footnotetext{
${ }^{5}$ In this context it can also be noticed that Nesset's $(2010,687)$ claim for Russian that "atelicity represents semantic overlap between po- and active perception" does not hold for Baltic to the same extent. In Latvian and Lithuanian it is very well possible to combine the delimitative prefix $p a$ - with opportunistic 'hear'.
} 
(2012, ch. 7) three-dimensional approach where each participant has its own subevent with its own aspectual structure. However, the aspectual structure of perception events is at least partly determined by the conditions for perception, which cannot be modeled in terms of subevents connected to participants.

The relevance of conditions is responsible for "the strange fact that for the physical perception verbs, the stative reading of see etc. (but not the inchoative) is equivalently expressed by can see, etc." (Dowty 1979, 132; ascribing this observation to Ryle 1949), which is characteristic at least for English, but much less so for many other languages. See and can see are often very close in their effect, which is because perception, and especially visual perception, is usually immediate and nearly effortless. This is not true for other kinds of events. I can write a book is not the same thing as I am writing/have written a book, because writing is everything else than immediate and effortless. As important as effort are constancy and constrainedness by external factors. As Rock $(1983,340)$ puts it, people hardly differ in their perceptions (except for phenomena such as color blindness). Hence conditions for information pickup implicate information pickup (but conditions for, say, writing or thinking do not implicate a particular kind of writing or thinking).

It is, of course, not the case that the special relationship between possibility and perception is restricted to 'state' perception. As we will see in Section 5, the expression of perception is generally modal as soon as conditions for perception are bad. In Section 4 I will argue that orientation toward conditions is crucial for understanding aspect in perception verbs and that aspectual theories must be able to account for conditions.

\section{(ix) Bias toward viewing activity in perception as control}

In some languages it is very clear that 'see' and 'hear' as opposed to 'look' and 'listen' is lack of control. In Kyirong Tibetan, for instance, a language where control is strictly grammaticalized, non-controllable verbs include 'forget', 'see', 'understand/know', 'hear' (with ergative-absolutive case marking) ${ }^{6}$ and 'get' and 'find' (with dative and absolutive case marking) (Huber 2005, 85). However, lack of control is not tantamount to absence of activity.

${ }^{6}$ According to Huber $(2005,85)$ the ergative marking shows that the grammatical role of Agent subsumes the semantic role of the perceiver. 
Opportunistic perception verbs (see, hear) focus on the opportunity of perception, i.e. exposure, what is called "proximal stimulus" by Rock (1983). Exposure is not directly controllable, but the person or animal can often provoke exposure by change of viewpoint through movement, which is why ambulatory vision ('go/come and see') is intermediate between opportunistic and explorative perception. But even more importantly, all perception presupposes attention and attention is activity. As Mack \& Rock $(1998,14)$ put it, "there is no conscious perception without attention." While non-conscious perception is an interesting psychological phenomenon, it is not experienced as perception and hence not verbalized as perception.

Mack \& Rock (1998) distinguish two kinds of attention in perception: voluntary/endogenous (attention before exposure) and captured/ exogenous attention (attention after exposure). Conscious perception after exposure is more likely to obtain if there is voluntary attention, and conflicting voluntary attention inhibits captured attention (inattentional blindness, Mack \& Rock 1998). Put differently, we are inclined to see what we expect to see. Hence, if attention is taken into account, it cannot be argued that opportunistic perception is entirely inactive. Accordingly, it makes sense that opportunistic perception can be construed by way of accomplishments, especially if there is a strong focus on voluntary attention, as in (4) above, which is a typical instance of opportunistic perception with voluntary attention.

Since it does not make sense to analyze see and hear as lacking activity entirely, I reject Dowty's (1979, 114) decompositional approach of 'perception activities' (look) as consisting of statives embedded in Do (i.e., $\mathrm{X}$ looks at $\mathrm{Y}$ is ' $\mathrm{X}$ does $\mathrm{X}$ sees $\mathrm{Y}$ ').

To summarize, there are at least nine heavy biases in the study of perception verbs in the traditional literature. It is necessary to be aware of them in order to open up for new solutions. Now it might, of course, be desirable to abandon all nine biases at the same time, but since this is difficult to achieve in practice, a more realistic approach is triangulation of several methods which are useful for accounting for different biases. This is the approach pursued in the following sections. In Section 3, I will address the discrete-feature bias at the cost of retaining the biases toward vision (and hearing) and nominalism by looking at data from parallel texts. In Section 4 I will address the biases toward participant orientation, aspectual event types, and physiology, by looking at examples from origi- 
nal texts in Lithuanian and Latvian in terms of psychological frameworks, hence reducing the bias toward nominalism, at the cost of retaining the discrete-feature bias which is difficult to avoid when looking at examples from one or a few particular languages. In Sections 5 and 6, some attempts will be made to overcome the vision bias. However, this paper will by no means complete the task of accounting for all biases. For instance, the bias toward a paradigmatic model of the lexical field of perception will only be marginally addressed in Section 3 .

\section{The lexical typology of 'hear' and 'see' in parallel texts and how the Baltic languages relate to it}

\subsection{Introduction}

Describing the meaning of a linguistic structure in a particular language or in a few closely related languages-as the Baltic languages in this paper-is best done in a cross-linguistic investigation, provided there are corpus data which are directly comparable on the level of language use. Only in a cross-linguistic investigation based on language use can the distortion of semantic space by language-particular categorization be overcome. Semantic studies based on a single language will almost inevitably suffer from a discrete-feature bias.

In this section I will look at the expression of auditory and visual perception in a world-wide convenience sample where languages of Europe making specificity distinctions in perception verbs and especially Baltic languages are strongly overrepresented. The data comes from a massively parallel text: the Gospel according to Mark. A more stratified sample might reveal that specificity is too rare cross-linguistically to be a general trend (this is a topic for further research), but this would not be particularly useful for studying the semantic factors underlying specificity. The risk of choosing a strongly biased sample is that the emerging picture will not reflect universal trends, but rather accidental properties of the languages in the sample. However, it still is better to generalize over several genealogically and areally strongly related languages than to consider just a single language variety. In a single language variety an encoded semantic distinction is almost always a strict distinction, due to the discrete nature of categorization. For investigating to what extent the underlying semantic space provides a strict opposition it is indispensable to consider a set of several languages (whether or not genealogically or 
areally related). Since the purpose of this paper is to find out what is going on in the Baltic languages within their European context, a sample biased toward Europe is actually more appropriate than a stratified sample. On the other hand, it is preferable not to restrict the sample to Europe in order to get some idea about how exotic the specificity distinction is in a global perspective. Keeping the door open for more diversity is also useful for detecting different, but related phenomena outside of Europe.

The approach pursued here is to induce the major trends from the data without any preconceived view on what the dominant semantic factors behind lexical differences are. For this aim we need a data-mining technique that can induce major trends from a database of lexical data. Such a technique is multidimensional scaling. ${ }^{7}$ Multidimensional scaling can be used to build probabilistic semantic maps from parallel texts (see Wälchli \& Cysouw 2012). Multidimensional scaling arranges the units to be visualized (here passages where perception verbs occur in the parallel text) such that the distance between any pair of units reflects the cross-linguistic distance in lexicalization. The closer two units reflecting particular passages in the text, the more likely that these are expressed by the same lexeme in any language of the sample. The underlying rationale is the isomorphism hypothesis that identity in form reflects similarity in meaning (Haiman 1985, 19). A sample of $n$ units can always be arranged within $n-1$ dimensions. Multidimensional scaling arranges the units such that the first dimension is most informative and that the second is more informative than the third etc. The dimensions do not come with qualitative labels, but have to be interpreted by way of manually going through the meaning of the examples at the poles. Here we will focus mostly on the first dimension generated by multidimensional scaling, which reflects the most important trend in the data. Probabilistic semantic maps are a convenient heuristic tool for identifying the major semantic trends in a lexical domain.

The choice of the Bible as a parallel corpus has the advantage that languages from many parts of the world can be included. A further advantage for some languages, including the Baltic languages, is that historical data are available. The major disadvantage, however, is that not all relevant contexts are represented. When choosing the NT we have to look at 'see' and 'hear' rather than 'smell', 'taste' and 'feel', i.e., it is not

${ }^{7}$ The R-function cmdscale() is used here. 
possible to overcome the bias toward vision (Section $2 \mathrm{iv}$ ). However, the advantage of overcoming the bias toward discrete features (Section 2 iii) prevails. It is moreover not possible to address the whole domain of sight and hearing. The phenomenon-based perception (Viberg 2001, 1295), such as looked happy, sounded sad is hardly represented in Mark and is fully excluded here. Finally, there are hardly any examples with difficult conditions for perception, which is why we cannot expect to find any obscured perception verbs. The closest we can come to this is 'see from a distance', which, however, will turn out to be highly relevant.

We will first look at explorative and opportunistic hearing (3.2) and sight (3.3) and then zoom in to opportunistic sight for the exploration of specificity (3.4).

It may not come as a surprise that 'see/look' is considerably more complex than 'hear/listen'. It is, for instance, well known that 'see/look' is more inclined to reflect suppletion for tense or aspect than 'hear/listen' (Veselinova 2006). To keep things simpler to start with, auditory perception comes first.

\subsection{Toward a semantic map of auditory perception}

Figure 2 shows a probabilistic semantic map (the first two dimensions) produced with multidimensional scaling from lexical verbs in 44 auditory contexts in the Gospel according to Mark in a world-wide convenience sample of 64 doculects $^{8}$ with a very strong bias toward Central and Eastern Europe. I use the term doculect here for a documented language variety (every translation of the Bible reflects one documented language variety) instead of language since it cannot be taken for granted that a particular text is representative for all varieties of that language. Actually a text is only representative of itself strictly speaking, and if there is much language-internal variation-which seems to be the case for perception verbs in many languages-it is not possible to make general claims about a language from the consideration of one text. Since our focus is the Bal-

\footnotetext{
${ }^{8}$ Abau, Albanian, Basque, Bulgarian, Catalan, Croatian, Czech, Danish, English (2x), Erzya Mordvin, Estonian, Faroese, Finnish, French (2x), German (neue), Bernese German, Gothic, Guaraní, Haitian Creole, Hausa, Hungarian, Icelandic, Indonesian, Italian, Kalmyk, Koine Greek, Latgalian, Latin, Latvian (3x), Lithuanian (4x), Livonian, Mandarin Chinese, Mandinka, Maori, Meadow Mari, Middle English, Modern Greek, Nalca, Norwegian, Old Church Slavonic, Ossetic, Polish, Romanian, Russian (2x), Samoan, Somali, Spanish, Swahili, Swedish (2x), Tajik, Tok Pisin, Turkish, Ukrainian, Vietnamese, Wolof.
} 
tic languages it is important to include several Lithuanian and Latvian translations. Here, eight Baltic Bible translations are included: for Lithuanian, the 1998 and 1984 translations, and the two older translations by Chyliński 1659 and Bretkunas 1580, for Latvian the 2012, 1965 and 1689 translations, and for Latgalian the 1933 translation. ${ }^{9}$

The location of passages is the same for all doculects in Figure 2 and is computed by multidimensional scaling so that for all doculects all lexemes cluster as much as possible. Each dot is a particular context expressed by an auditory verb ('hear' or 'listen') and the distance between any pair of dots reflects the probability that these two contexts will be expressed by the same verb in any language.

Very few languages of the sample strictly lexicalize a distinction between 'listen' (explorative) and 'hear' (opportunistic). Modern English is rather exceptional in this respect. Some languages, including Koine Greek (not shown), the source language of the text, have the same verb for all contexts: akoúo 'hear, listen'. The NT happens to have many instances of ability contexts (e.g., if anyone has ears to hear) which are neither clearly explorative nor clearly opportunistic; in English these go with hear. In Mandarin Chinese, Bulgarian, and partly in Lithuanian, however, they go with 'listen'.

The Baltic and Slavic languages differ among themselves where they draw the borderline between specific and non-specific 'hear'. Like Gothic specific gahausjan (not shown) and Ossetic specific fequsan, Bulgarian čuja 'hear[PFV/SPEC]' has a larger distribution than Lithuanian išgirsti 'hear[SPEC]' which, in its turn, is more widely used than Latgalian izdzirst/ izdzirdēt 'hear[SPEC]' which is again more frequent than Latvian izdzirdett 'hear[SPEc]'. Russian, Ukrainian and Polish have a cut-off point similar to Modern Lithuanian. In the Baltic languages there seems also to be a diachronic cline. In the Latvian Glück translation from 1689, izdzirdett 'hear[SPEC]' does not occur at all in Mark, and in the Old Lithuanian Bretkunas Bible, išgirsti is less frequent than in the other three Lithuanian translations. The diachrony of Baltic perception verbs is further discussed in 7.3. In Hungarian (not shown) specific meghall 'hear[sPEc]' is largely restricted to contexts with definite objects (Dickey 2000, 269). This is not paralleled in any other language of the sample.

${ }^{9}$ The resulting configuration is almost the same if only three Baltic translations are included, so the Baltic bias does not alter the basic configuration of the semantic map. 
Figure 2. Probabilistic semantic map of 44 auditory contexts in Mark based on 64 doculects in English (leb), Lithuanian (1998), Latgalian, Latvian (2012), Bulgarian, and Mandarin Chinese

$=$ specific 'hear', $\Delta=$ non-specific 'hear', $\mathrm{O}=$ 'listen'

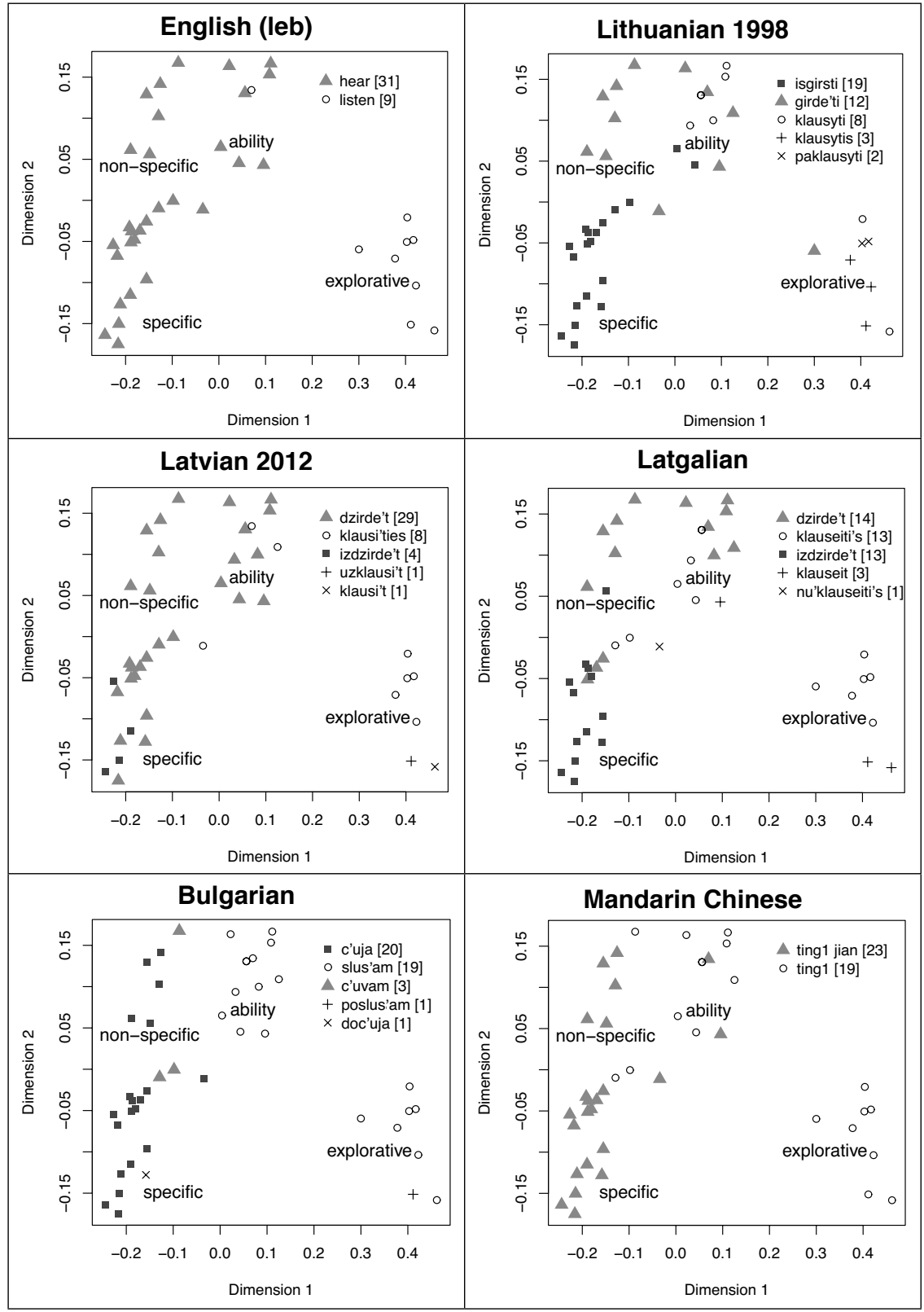


Opportunistic contexts are of two kinds: (i) hearing a verbal message (higher-level) and (ii) hearing non-verbal sounds. The examples in Mark happen to be exclusively of the verbal type (ii) which testifies to the importance of hearing speech in human auditory perception ${ }^{10}$ and of the importance of higher-level perception for hearing.

Mandarin Chinese is included in Figure 2 because it has a peculiar property which is highly important for lexical aspect (see also Section 2 vii). It has only a verb stem for 'listen': ting $^{1}$ (also for 'hear' ability) whereas opportunistic 'hear' is expressed by a resultative compound ting ${ }^{1}$ jian $\left(^{4}\right)$ [listen-perceive] 'hear'. Mandarin also illustrates a language with a distributionally rather restricted expression for 'hear' which does not, however, distinguish specific and non-specific 'hear'. In Bulgarian, 'hear' also has a restricted distribution and non-specific (=imperfective) is strongly restricted, in particular to iterative contexts such as, 'whenever they hear the word' (Mark 4:15). This is not astonishing when viewed in a diachronic context. In Bulgarian the imperfective verb is a secondary, originally iterative, derivation (čuvam), unlike other Slavic languages where the imperfective verb is morphologically basic for 'hear'.

We can conclude that opportunistic and explorative contexts form a scale (Dimension 1 in the MDs-plots) with specific opportunistic contexts being at the extreme of the opportunistic pole and with ability contexts being intermediate between opportunistic 'hear' and explorative 'listen'.

Let us now turn to visual perception.

\subsection{Toward a semantic map of visual perception}

When we apply the same procedure to 85 visual situations in the Gospel according to Mark in a similar world-wide convenience sample of 65 doculects, ${ }^{11}$ the emerging pattern is more complex. This is mainly because looking is considerably more diverse in its cross-linguistic expression

\footnotetext{
${ }^{10}$ In Ewe, a language which tends to have empty objects (often $n u$ 'thing') where other languages do not express an object, the empty object for se 'hear' is nya 'word'.

11 Abau, Albanian, Basque, Bulgarian, Chechen, Croatian, Czech, Danish, Dinka, English (2x), Erzya Mordvin, Estonian, Finnish, French, German, Bernese German, Gothic, Guaraní, Haitian Creole, Hausa, Hungarian, Icelandic, Imbabura Quechua, Indonesian, Italian, Koine Greek, Latgalian, Latin, Latvian (3x), Lithuanian (4x), Livonian, Mandarin Chinese, Mandinka, Maori, Mapudungun, Meadow Mari, Middle English, Modern Greek, Nakanai, Nalca, Norwegian, Old Church Slavonic, Ossetic, Polish, Romanian, Russian, Samoan, Somali, Spanish, Swahili, Swedish (2x), Tagalog, Tajik, Tok Pisin, Turkish, Ukrainian, Vietnamese, Wolof
} 
than listening. In multidimensional scaling this is reflected in that the explorative domain on the right hand side in plot is scattered, whereas opportunistic 'see' clusters very strongly.

One reason why explorative vision has so many different expressions is the relevance of directions: 'look around', 'look up', 'look down', although some directions are not even represented in Mark. There is 'look up' and 'look around', but, for instance, 'look back', 'look down', or 'look into' do not occur in Mark. ${ }^{12}$

As in auditory perception, there is no clear borderline between opportunistic and explorative vision. An important intermediary context is ambulatory vision 'go and see', which is both opportunistic-movement creates an opportunity to see-and explorative-active search for information pickup. Ambulatory vision in Lithuanian and Latgalian is preferably expressed by delimitative looking-Lithuanian pažiūrèti [DELIM.look. INF], Latgalian pasaverrt [DELIM.RFL.look.INF] (as in Russian posmotret' [DELIM.look.INF]) whereas Latvian has both redzèt 'see', and raudzit, one of four different bases that can be translated with 'look' (lūkot, skatit(ies), $v \bar{e} r o t$, raudzit), but no prefix. Like a number of Slavic languages, Lithuanian has a verb for inchoative ability vision: praregeti [before.see.INF] with the prefix pra- 'before' which combines with the less frequent nonspecific verb for 'see', regeti.

\footnotetext{
12 The expression of directed looking is very diverse and rather unsystematic across Baltic. It is partly formed with prefixes, but no prefix can be used for 'up' in the modern languages. Latvian has pacelt acis [PVB.rise.INF eye.ACC.PL] 'look up' instead. For 'look around', Lithuanian has a prefix and an iterative derivation: apžvalgyti [around.look.ITER.INF].
} 
Figure 3. Probabilistic semantic map of 85 visual contexts in Mark based on 65 doculects in Lithuanian and Latvian

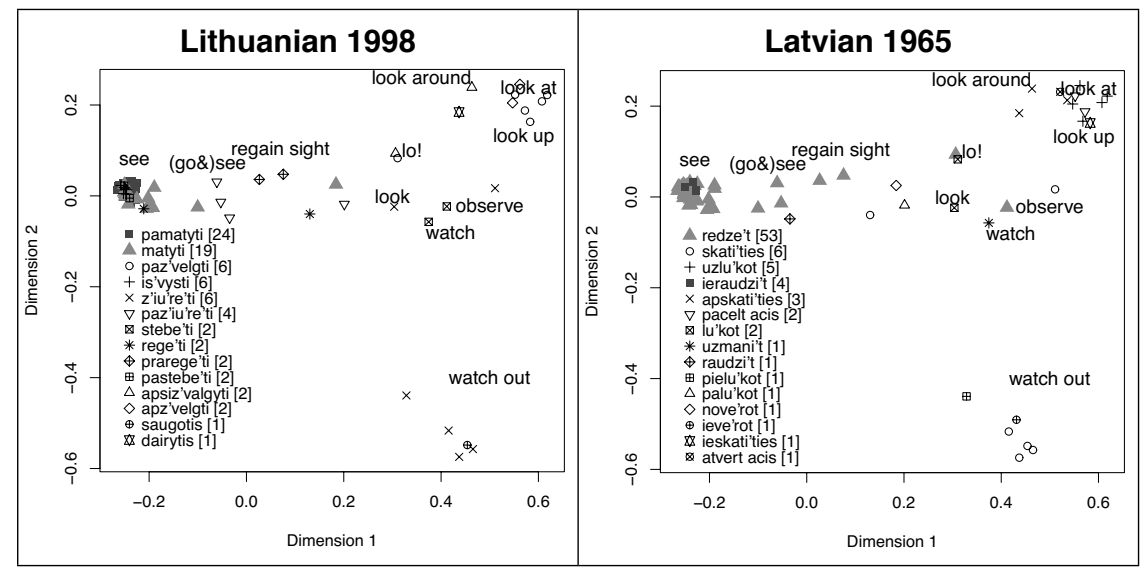

Much more could be said about the semantic map of 'looking', but since explorative vision is not the major topic of this paper, this has to be done elsewhere. The most important conclusion is that opportunistic vision is much more compact in conceptual space than explorative vision.

\subsection{Toward a semantic map of (non-)specific 'see'}

In order to explore what happens in the tight 'see' cluster to the left, we have to zoom in. The same procedure is applied now only to the 51 most typical 'see' contexts. Most of the 65 doculects of the sample have now a single dominant verb lexicalizing all contexts although there is only a small minority (15 doculects) where only one lexeme is attested (suppletive tense/aspect stems in Tajik [present], Albanian [present] and Modern Greek [imperfective] are counted as different lexemes).

Figure 4 shows eight texts from languages which arguably make some sort of specificity distinction even though German erblicken at one extreme pole is very rudimentary in extension (occurs only once in Mark), and Ossetic fenan, on the other extreme pole, covers almost everything (Gothic not shown here, is even more extreme than Ossetic, but displays a less neat distribution). Ossetic fenən 'see[SPEC]' almost completely corresponds to Koine Greek blépō (which turns into the suppletive imperfective stem for 'see' in Modern Greek). It might thus be argued that Koine 
Greek, the source language of the NT, also makes a specificity distinction. It differs, however, from Ossetic, Gothic and Bulgarian with similar distributions for 'see' in that the distinction does not recur in 'hear'.

Figure 4. Probabilistic semantic map of 51 'see' contexts in Mark based on 65 doculects in German, Latvian, Croatian, Latgalian, Polish, Lithuanian, Ukrainian and Ossetic

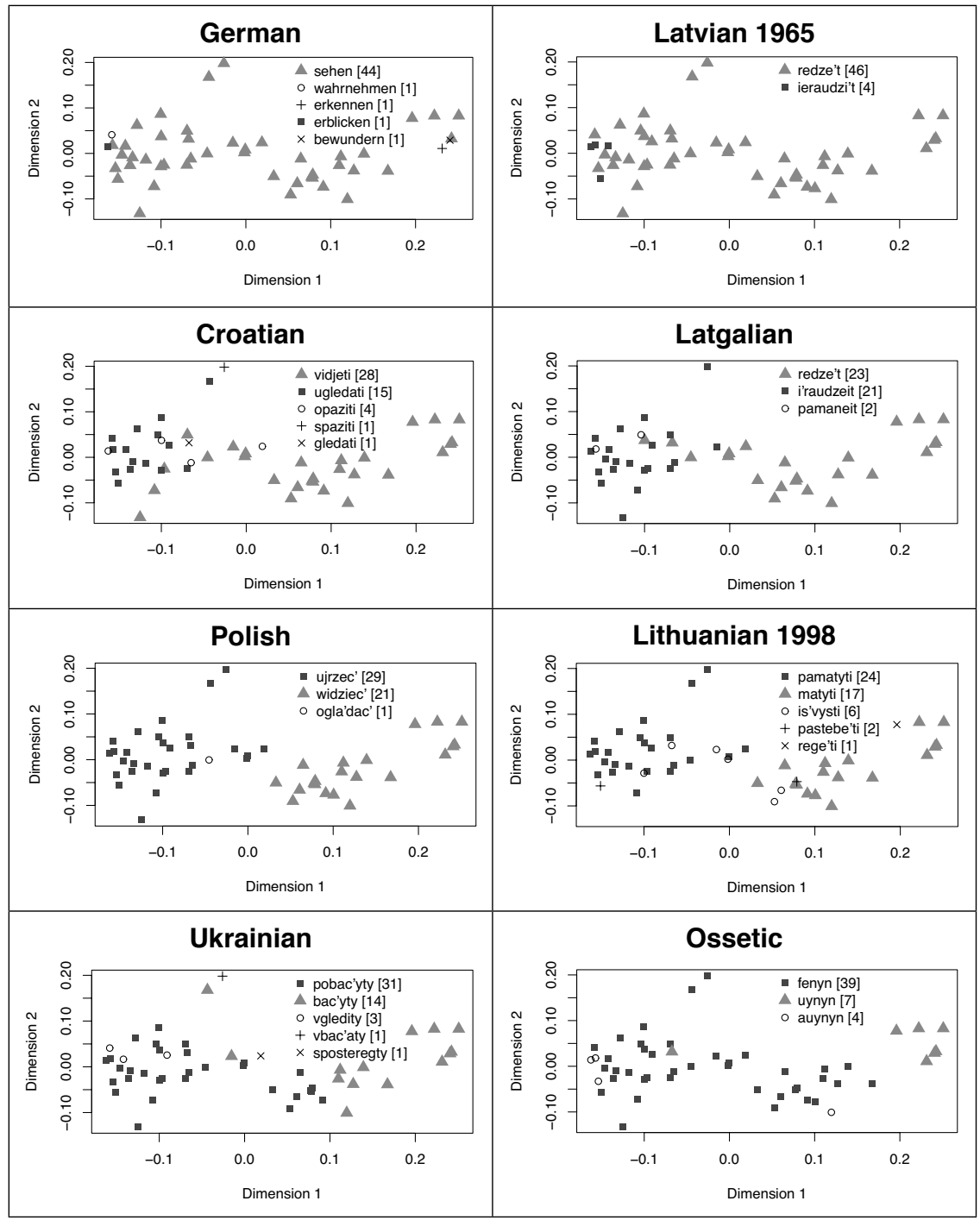


Figure 4 illustrates the specificity cline in German (neue), Latvian (1965), Croatian, Latgalian (1933), Polish, Lithuanian (1998), Ukrainian, and Ossetic. In all these doculects the cut-off point is at a different place on the specificity cline, which is the major trend in the data set (Dimension 1 in the MDs-analysis).

In order to understand the semantic structure of the specificity cline we have to look at the examples that constitute the cline. Since there is no space for a discussion of all 51 examples here, Table 3 singles out nine passages that are characteristic of larger groups of examples. Figure 5 is the specificity cline that results from the semantic interpretation of these groups.

Figure 5. Specificity cline (approximation based on selected examples in Mark for visual perception)

A: see from a distance $(5: 6)>$

B: recognize while approaching (14:69) >

C: see one or few persons for the first time $(1: 16)>$

D: see an event or a crowd (16:15) >

E: see in future tense $(16: 7)>$

F: see an event in progress $(2: 16 ; 6: 48)>$ G: experiential $(2: 12)>$

$\mathrm{H}$ : present tense with speech act participant as subject (3:2)

Table 3. Specificity cline illustrated with nine contexts in nine translations of the Gospel according to Mark

\begin{tabular}{|c|c|c|c|c|c|c|c|c|c|c|}
\hline & & & deu & $\begin{array}{c}\text { lav } \\
1965\end{array}$ & $\begin{array}{c}\text { swe } \\
2000\end{array}$ & ltg & ces & $\begin{array}{c}\text { lit } \\
1998\end{array}$ & $\mathrm{ukr}$ & OSS \\
\hline$\overline{\mathrm{A}}$ & $5: 6$ & $\begin{array}{l}\text { And when he saw } \\
\text { Jesus from a dis- } \\
\text { tance, he ran and } \\
\text { knelt down before } \\
\text { him. }\end{array}$ & $\mathrm{X}$ & $\mathrm{x}$ & $\mathrm{x}$ & $\mathrm{X}$ & $\mathrm{X}$ & $\mathrm{X}$ & $\mathrm{X}$ & $\mathrm{X}^{*}$ \\
\hline B & $14: 69$ & $\begin{array}{l}\text { And the female } \\
\text { slave, when she saw } \\
\text { him, began to say } \\
\text { again to the bystand- } \\
\text { ers: }\end{array}$ & & $\mathrm{X}$ & $\mathrm{x}$ & $\mathrm{X}$ & $\mathrm{X}$ & $\mathrm{x}$ & $\mathrm{X}^{*}$ & $\mathrm{x}$ \\
\hline
\end{tabular}


Continuation of Table 3

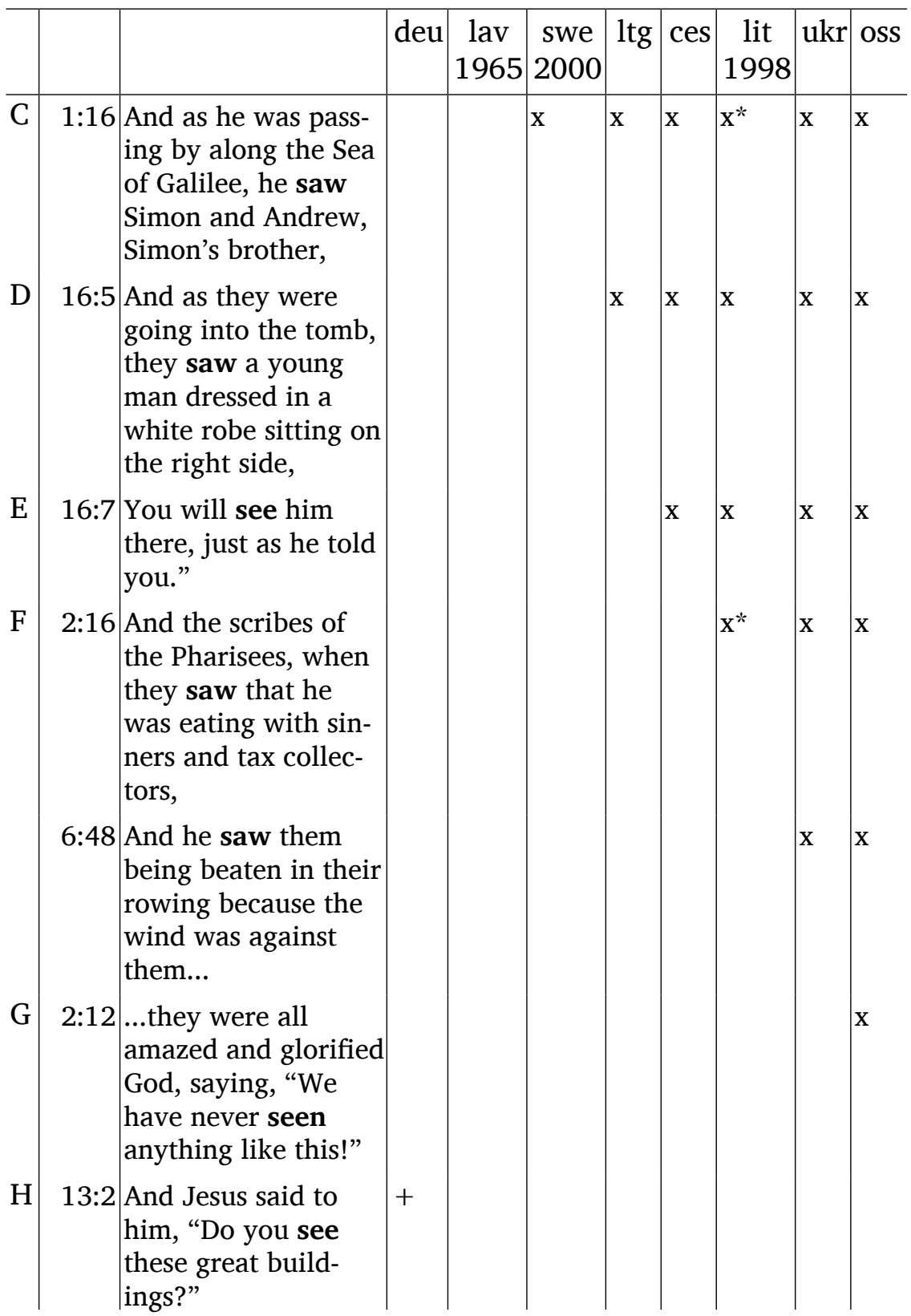

$\mathrm{x}$ : dominant specific verb attested in that passage, $\mathrm{x} *$ less frequent secondary specific verb form attested in that passage. 
+ : explorative verb: German bewundern "admire" (deu-neue: Du bewunderst diese großen Gebäude?)

Specific verbs: German erblicken (1x), Latvian ieraudzit (4x), Swedish (2000) få se (13x) and få syn på (2x), Latgalian iraudzeit (21x), Czech uzř́t (28x), Lithuanian pamatyti (24x), išvysti (6x), Ukrainian pobačyty (31x), vgledity (3x), Ossetic fenən (39x), awənən (4x)

Figure 6 shows the doculects of the sample that in some way contribute to the specificity scale. Every row is a passage in the parallel text ordered top-down according to Dimension 1 of the multidimensional scaling. $\mathrm{x}$ is a specific form, dot is a non-specific form and backslash is a nonattested form or one that cannot be classified. The doculects are given in ascending order for specificity tokens with three-letter codes and with numbers in chronological order if more than one per language. From left to right Danish (dan), German (neue) (deu), Mandinka (mnd), Tagalog (tg1), Latvian 1689 (lav1), Norwegian (nob), Latvian 1965 (lav2), Old Church Slavonic (chu), Hungarian (hun), Swedish 2000 (swe2), Latvian 2012 (lav3), Lithuanian 1580 (lit1), Croatian (hrv), Latgalian (ltg), Swedish 1917 (swe1), Lithuanian 1984 (lit3), Czech (ces), Polish (pol), Lithuanian 1998 (lit4), Lithuanian 1659 (lit2), Russian (ibt) (rus), Ukrainian (ukr), Gothic (got), Bulgarian (bul), Koine Greek (grc), Ossetic (oss). 


\section{Figure 6. Doculects ordered on specificity scale}

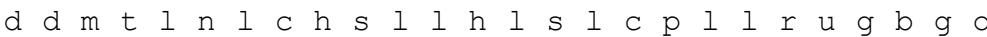
$\mathrm{a} e \mathrm{ng}$ a $\circ \mathrm{a} \mathrm{h} u \mathrm{w}$ a $\mathrm{r} t \mathrm{w}$ i $e \circ \mathrm{i} u \mathrm{k} \circ \mathrm{u}$ r $\mathrm{s}$

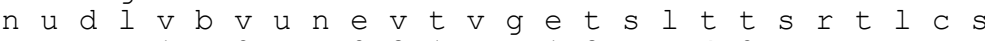
$\begin{array}{llllllllllll}1 & 2 & 2 & 3 & 1 & 1 & 3 & 4 & 2\end{array}$

\begin{tabular}{|c|c|c|c|c|c|c|c|c|c|c|c|c|c|c|c|c|c|c|c|c|c|c|c|c|c|c|c|c|}
\hline & $x$ & $\mathrm{X}$ & $\mathrm{X}$ & & • & $\mathrm{X}$ & $\mathrm{X}$ & $\mathrm{X}$ & $x$ & $x$ & . & $\mathrm{X}$ & $\mathrm{X}$ & $\mathrm{X}$ & $\mathrm{X}$ & $\mathrm{X}$ & $\bar{X}$ & $\bar{X}$ & & $\mathrm{X}$ & $\mathrm{X}$ & $\mathrm{X}$ & $\mathrm{X}$ & $\mathrm{X}$ & $\mathrm{X}$ & $\mathrm{X}$ & $\bar{A}$ & \\
\hline & . & . & . & . & • & $x$ & . & $\mathrm{x}$ & $x$ & $x$ & $x$ & $x$ & $x$ & $x$ & $x$ & $x$ & $x$ & $V$ & 1 & $x$ & X & $x$ & $x$ & $x$ & $\mathrm{x}$ & $x$ & B & \\
\hline & . & . & . & . & . & . & . & $x$ & $x$ & . & $x$ & $x$ & $x$ & $x$ & $x$ & $x$ & $x$ & $x$ & 3 & $x$ & $x$ & $x$ & $x$ & $\mathrm{x}$ & $\mathrm{x}$ & $x$ & B & \\
\hline & . & $x$ & $x$ & . & . & $x$ & . & $x$ & $x$ & $x$ & • & $x$ & 1 & $x$ & $x$ & $x$ & $\mathrm{x}$ & $x$ & & $x$ & $x$ & $x$ & $x$ & $x$ & $\mathrm{x}$ & $x$ & A & \\
\hline X & . & $\cdot$ & . & . & $\mathrm{X}$ & . & . & . & $x$ & • & $\mathrm{X}$ & $\backslash$ & $\mathrm{X}$ & $\mathrm{X}$ & $\mathrm{X}$ & $\mathrm{x}$ & $\bar{x}$ & $\bar{X}$ & $\bar{z}$ & $\mathrm{X}$ & $\mathrm{X}$ & $\mathrm{x}$ & $\mathrm{x}$ & $\mathrm{X}$ & $\backslash$ & $\mathrm{X}$ & $\bar{B}$ & \\
\hline & . & . & . & . & . & . & . & $x$ & $x$ & $x$ & $x$ & $x$ & $x$ & $x$ & $x$ & $x$ & $x$ & $x$ & 3 & $x$ & $\mathrm{x}$ & $x$ & $x$ & $x$ & $x$ & $x$ & $B$ & \\
\hline & . & . & . & - & $x$ & $x$ & . & $x$ & $x$ & $x$ & • & $x$ & $x$ & $x$ & $x$ & $x$ & $x$ & $x$ & & $x$ & $x$ & $x$ & $x$ & $x$ & $x$ & $x$ & B & \\
\hline & . & . & . & . & . & . & $\mathrm{x}$ & • & $\mathrm{x}$ & $\mathrm{x}$ & $\mathrm{X}$ & $\mathrm{X}$ & $\mathrm{X}$ & $\mathrm{x}$ & $\mathrm{X}$ & $\mathrm{X}$ & $\mathrm{X}$ & $x$ & 3 & $\mathrm{X}$ & $\mathrm{X}$ & $x$ & $x$ & $x$ & $\mathrm{X}$ & $\mathrm{X}$ & $\mathrm{C}$ & \\
\hline & . & . & . & - & . & . & . & $x$ & $x$ & $x$ & $x$ & $x$ & $x$ & $x$ & $x$ & $x$ & $x$ & $x$ & $z$ & $x$ & $\mathrm{x}$ & $x$ & $x$ & $x$ & $x$ & $x$ & $\mathrm{C}$ & \\
\hline & . & . & . & $\mathrm{x}$ & 1 & . & . & . & $\backslash$ & $x$ & 1 & . & $x$ & $x$ & 1 & $x$ & $x$ & 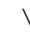 & 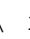 & $x$ & $x$ & $x$ & $\backslash$ & $x$ & $x$ & $x$ & $\mathrm{C}$ & \\
\hline & . & . & . & - & . & . & $x$ & $x$ & $x$ & • & $x$ & $x$ & $x$ & $x$ & $x$ & $x$ & $x$ & $x$ & & $x$ & $x$ & $x$ & $x$ & $x$ & $\mathrm{x}$ & $x$ & $E$ & \\
\hline & . & . & . & - & . & . & . & . & $x$ & $x$ & $x$ & $x$ & $x$ & $x$ & $x$ & $x$ & $x$ & & & $x$ & $\mathrm{x}$ & $x$ & $x$ & $x$ & $\mathrm{x}$ & $\mathrm{X}$ & $\mathrm{C}$ & \\
\hline & . & . & . & . & . & . & . & $\mathrm{X}$ & $T$ & $\mathrm{x}$ & $\mathrm{x}$ & $\mathrm{x}$ & $T$ & $x$ & $x$ & $x$ & $\bar{x}$ & $x$ & 8 & $\mathrm{X}$ & $\mathrm{x}$ & $x$ & . & . & $\mathrm{X}$ & $\mathrm{X}$ & $\mathrm{C}$ & \\
\hline & . & . & . & $\cdot$ & . & . & . & . & $x$ & $x$ & • & . & $x$ & $x$ & $x$ & $x$ & $x$ & $x$ & 3 & $x$ & $x$ & $x$ & $\backslash$ & $\mathrm{x}$ & $\mathrm{x}$ & $x$ & $\mathrm{D}$ & \\
\hline & . & . & . & $\cdot$ & . & . & . & . & $x$ & $x$ & $x$ & . & $x$ & $x$ & $x$ & $x$ & $x$ & $x$ & 8 & $x$ & $x$ & $x$ & 1 & $\mathrm{x}$ & $\mathrm{x}$ & $\mathrm{X}$ & $D$ & \\
\hline & . & . & . & $\mathrm{X}$ & . & . & . & . & . & $x$ & $\cdot$ & $x$ & $x$ & $x$ & 1 & $x$ & $x$ & $x$ & $\mathrm{z}$ & $x$ & $x$ & $x$ & $x$ & . & 1 & $x$ & $\mathrm{D}$ & \\
\hline & . & . & . & . & . & . & . & . & . & $x$ & $x$ & $x$ & $x$ & . & $x$ & $x$ & $x$ & $x$ & 3 & . & $x$ & $x$ & $x$ & $x$ & $x$ & $x$ & $\mathrm{D}$ & \\
\hline & . & . & . & • & $x$ & . & . & . & . & $x$ & $x$ & $x$ & • & $x$ & $x$ & $x$ & $x$ & $x$ & & $x$ & $x$ & $x$ & $x$ & $x$ & $\mathrm{x}$ & $x$ & D & \\
\hline & . & . & . & - & . & . & . & . & . & $x$ & $\mathrm{x}$ & $x$ & $x$ & $x$ & $x$ & $x$ & $\mathrm{x}$ & $x$ & & $x$ & $x$ & $x$ & $x$ & $x$ & $x$ & $\mathrm{x}$ & D & \\
\hline & . & . & . & - & . & . & $\mathrm{X}$ & $\mathrm{X}$ & . & . & $\mathrm{X}$ & • & . & $\mathrm{X}$ & $x$ & $\mathrm{X}$ & $\mathrm{X}$ & & & $\mathrm{X}$ & $x$ & $x$ & $x$ & $x$ & $\mathrm{X}$ & $\cdot$ & $E$ & \\
\hline & . & . & . & • & . & . & $x$ & . & . & . & $x$ & . & $x$ & $x$ & $x$ & $x$ & $x$ & $x$ & 3 & $x$ & $x$ & $x$ & $\backslash$ & $x$ & $x$ & $x$ & $E$ & \\
\hline & . & . & . & • & . & . & . & • & . & . & • & $x$ & $x$ & $x$ & $x$ & $x$ & $x$ & $x$ & 8 & $x$ & $x$ & $x$ & $x$ & $x$ & $\mathrm{x}$ & $x$ & $\mathrm{D}$ & \\
\hline & . & . & . & $\cdot$ & • & • & - & • & . & $x$ & $x$ & $x$ & $x$ & . & $x$ & $x$ & $x$ & $X$ & 3 & . & $x$ & $x$ & $x$ & $x$ & $\mathrm{X}$ & $x$ & $\mathrm{D}$ & \\
\hline & . & . & . & - & . & . & . & $x$ & $x$ & . & . & . & . & $x$ & . & $x$ & $x$ & & z & $x$ & $x$ & $x$ & $x$ & $x$ & $\mathrm{x}$ & $x$ & $E$ & \\
\hline & . & . & . & - & . & . & . & . & . & . & $x$ & $x$ & 1 & $x$ & $x$ & . & $x$ & $x$ & 3 & $x$ & $x$ & . & $x$ & . & $\backslash$ & $x$ & $\mathrm{D}$ & \\
\hline & . & . & . & . & . & . & . & $x$ & . & . & $x$ & $\backslash$ & $x$ & . & $x$ & $x$ & $x$ & $x$ & 8 & $x$ & . & $x$ & $x$ & . & 1 & $x$ & $X$ & \\
\hline & . & . & . & • & . & . & . & $x$ & . & . & . & . & $x$ & $x$ & $x$ & $x$ & $x$ & & 3 & $x$ & $x$ & . & $x$ & $x$ & $x$ & $x$ & $E$ & \\
\hline & . & . & . & • & . & . & . & . & . & . & . & . & . & $x$ & . & $x$ & $x$ & $x$ & 8 & $x$ & $x$ & $x$ & $x$ & $x$ & $x$ & $x$ & $E$ & \\
\hline & . & . & . & $\cdot$ & . & . & . & . & . & . & 1 & . & . & . & $x$ & $x$ & $x$ & $x$ & 8 & $x$ & $x$ & $x$ & $x$ & $x$ & $\mathrm{x}$ & $x$ & $E$ & \\
\hline & . & . & . & • & . & $\cdot$ & . &. & . & . & $\cdot$ & $\mathrm{X}$ &. & . & . & . & $\mathrm{X}$ & 8 & $\mathrm{~s}$ & $\mathrm{X}$ & $\mathrm{X}$ & $\mathrm{x}$ & $x$ & $\mathrm{X}$ & $\mathrm{X}$ & $\mathrm{X}$ & $\mathrm{F}$ & \\
\hline & . & . & . & . & . & . & . & . & . & . & . & . & . & . & . & $x$ & . & . & & $x$ & $x$ & $x$ & $x$ & $x$ & $\mathrm{x}$ & $x$ & $\mathrm{~F}$ & \\
\hline & . & . & . & - & . & • & . & . & - & - & . & . & . & . & . & . & . & $x$ & 3 & $x$ & $x$ & $x$ & $x$ & $x$ & $x$ & $x$ & $\mathrm{~F}$ & \\
\hline & . & . & . & . & . & . & . & . & $x$ & . & . & . & . & . & . & . & . & $x$ & & . & $x$ & $x$ & $x$ & $x$ & $\mathrm{x}$ & $x$ & $F$ & \\
\hline & . & . & . & $\cdot$ & . & . & . & 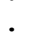 & • & . & $\cdot$ & . & • & • & $\cdot$ & • & . & 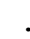 & & $\mathrm{x}$ & $x$ & $x$ & $x$ & $x$ & $x$ & $x$ & $\mathrm{~F}$ & \\
\hline & . & . & . & $\cdot$ & . & . & • & . & . & • & • & . & . & • & $x$ & • & . & . & & . & . & $x$ & 1 & $x$ & $x$ & $x$ & $\mathrm{~F}$ & \\
\hline & . & . & . & . & . & . & . & $x$ & . & • & . & . & . & . & . & . & . & 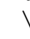 & 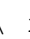 & $x$ & . & $x$ & 1 & $\mathrm{X}$ & $x$ & $x$ & $\mathrm{~F}$ & \\
\hline & 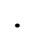 & . & . & • & • & . & • & • & - & • & . & . & $\backslash$ & . & . & . & . & 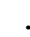 & & $\backslash$ & • & $x$ & $x$ & $\mathrm{x}$ & $\mathrm{x}$ & 1 & $\mathrm{~F}$ & \\
\hline & . & . & . & - & . & $\cdot$ & $\cdot$ & - & . & . & . & . & . & $\bullet$ & • & • & • & . & & & $x$ & $x$ & $\backslash$ & $\mathrm{x}$ & $\mathrm{x}$ & $x$ & $\mathrm{~F}$ & \\
\hline & . & . & . & - & . & . & . & . & . & • & . & 1 & 1 & . & . & . & . & 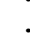 & & . & 1 & $\backslash$ & $x$ & $x$ & $x$ & $x$ & $\mathrm{~F}$ & \\
\hline & . & . & . & . & . & . & • & • & - & . & • & . & 1 & • & • & - & • & . & & • & . & . & $x$ & $\mathrm{x}$ & 1 & $\mathrm{x}$ & $\mathrm{G}$ & \\
\hline & . & . & . & • & . & 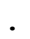 & 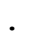 & • & . & • & . & . & $\backslash$ & . & . & • & • & . & & . & $\cdot$ & . & $x$ & $\mathrm{x}$ & $x$ & $\mathrm{x}$ & $\mathrm{G}$ & \\
\hline & . & . & . & - & . & . & $\cdot$ & . & . & . & $\cdot$ & . &. & • & • & • & • & . & t. & . & $x$ & 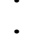 & $x$ & $\mathrm{X}$ & $\mathrm{x}$ & $x$ & $Y$ & $\mathrm{~N}$ \\
\hline & . & . & . & • & • & . & • & • & • & . & $\cdot$ & $\cdot$ & . & . & . & . & • & . & & . & . & . & . & $\mathrm{x}$ & $x$ & $x$ & $\mathrm{G}$ & \\
\hline & . & . & • & - & . & . & . & . & - & . & • & • & . & • & . & • & • & . & & . & - & . & $x$ & $\mathrm{x}$ & 1 & $x$ & $\mathrm{G}$ & \\
\hline & . & . & . & • & . & . & . & • & • & • & $\cdot$ & . & • & . & $\cdot$ & • & • & . & & . & . & . & $x$ & . & $x$ & $x$ & $\mathrm{G}$ & $\mathrm{N}$ \\
\hline & $\cdot$ & . & . & . & $\cdot$ & . & . & . & . & . & $\cdot$ & $\cdot$ & . & . & $\cdot$ & $\cdot$ & . & 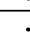 & & $\cdot$ & . & $\cdot$ & $x$ &. & . & • & $\mathrm{H}$ & \\
\hline & . & . & . & • & . & . & 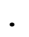 & . & . & . & . & $\bullet$ & . & $\cdot$ & . & . & $\bullet$ & . & & . & • & . & . & . & . & $\bullet$ & $\mathrm{H}$ & $\mathrm{N}$ \\
\hline & $\theta^{\circ}$ & • & • & & $\cdot$ & $\cdot$ & $x$ & - & - & $\cdot$ & . & & • & $\cdot$ & • & • & & . & & & • & . & $x$ & . & 1 & $\cdot$ & $\mathrm{Z}$ & \\
\hline & . & . & . & - & . & . & . & $\cdot$ & • & - & $\cdot$ & • & $\cdot$ & $\cdot$ & 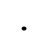 & 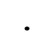 & & . & & & ${ }^{\circ}$ & . & $\backslash$ & • & $x$ & $\cdot$ & $\mathrm{H}$ & \\
\hline & . & . & . & • & . & . & . & . & . & . & . & • & . & . & . & . & & & & & $\cdot$ & . & $\backslash$ & . & . & $\cdot$ & $\mathrm{H}$ & \\
\hline & . & . & . & . & . & . & . & . & - & - & . & • & . & . & - & . & • & & & . & . & . & $x$ & . & . & • & $\mathrm{H}$ & $\mathrm{N}$ \\
\hline
\end{tabular}


A-H: see Figure 5 and Table 3; X: iterative ('whenever they saw him'); Y: indefinite ('saw one') ; Z 'saw all things clearly'; N: negation

Some doculects do not easily fit the cline, notably Old Church Slavonic, Hungarian and Bulgarian. Old Church Slavonic has six occurrences of uzbrěti 'see[SPEc]', spread over the whole cline from A to H. Hungarian meglát deviates because it exhibits a different semantic pattern (definiteness of object) than all other languages in the sample with a specificity distinction. Bulgarian specific vidja extends from A to G, but there are also four occurrences on the top segment of Dimension 2 further to the left on Dimension 1. One of them is iterative (X) where also Russian has imperfective aspect and where Ukrainian uses a specific secondary imperfective (vbačaty 'see[sPEc/IPFV]').

Both in Latvian and in Lithuanian there is an increase of number of specific 'see' tokens from the earliest translations. In Latvian 1689 ieraudzit is not attested on the extreme pole of the specificity cline (see from a distance), but in two contexts with purposive or consecutive function ('And he was looking around to see...' 5.32; 'And they came to Jesus and saw...' 5.15), one of which is ambulatory vision. These are the contexts where an explorative accomplishment (the base of ieraudzit is raudzit and means 'look, watch') can turn into specific opportunistic 'see'. What distinguishes all Latvian translations is that future contexts are non-specific. In Lithuanian, future contexts with specific išrysti are already attested in 1580 .

It is important to note that the specificity cline in Figure 6 is based only on vision, so it cannot be taken for granted that other sense modalities follow the same cline.

The most important results are (i) that there is a cline rather than a strict opposition recurring across doculects and (ii) that this cline cannot be explained in terms of inceptive states. The extreme pole to the left 'see from distance' has rather to do with the conditions of perception than with the temporal-aspectual structure of perception events. Support for the importance of seeing from distance comes from two languages in the sample which have particular verbs for 'see (from distance)': Mandinka hayinay and Tagalog tumanaw. ${ }^{13}$ To what extent 'see (from distance)' is relevant for specificity has to be clarified by future research.

${ }^{13}$ The closest parallel to a verb 'see (from distance)' in Baltic is Lithuanian užvysti which differs from išvysti 'see[SPEC]' in the prefix, e.g. Nuo jos viršūnès galima užvysti Kalakmulį. [from 3.GEN.SG.F top.GEN.sG possible see[distance].INF Calakmul.ACC.sG] 'from its top [the top of El 


\section{Psychological approaches and the relevance of the conditions of perception}

In this paper I frequently adduce James J. Gibson's ecological approach to perception and Irvin Rock's theory of indirect perception, which both reject the traditional view of a purely stimulus-based approach to perception. However, it is important to note that the two theories are not fully compatible. According to Gibson, perception is direct; according to Rock it is a cognitive process of problem solving in a chain of causation where the final perception is indirect. However, while what are the simple and basic units for Gibson are higher-level percepts for Rock, both approaches have in common that they shift away the focus from the physiological stimulus. Notably they both emphasize the relevance of conditions of perception: Gibson's ecological approach by focusing on the role played by the environment, and Rock's indirect approach by pointing out that perception is unique among cognitive processes in being constrained by the necessity of accounting for the proximal stimulus. In this section I will first introduce some basic elements of Gibson's and Rock's approaches to perception and then illustrate the relevance of conditions for understanding the semantics of specific and non-specific perception verbs in the Baltic languages.

According to the ecological approach to perception, which is opposed to the traditional view in physiological optics and psychology, perception is direct and not mediated by retinal, neural, or mental pictures. (Seeing a picture is a combination of "a direct perceiving of the picture surface along with an indirect awareness of what it depicts"; Gibson 1979, 291). Even though Rock (1997) does not deny the existence of a retinal image, he is even more radical than Gibson in arguing against the relevance of retinal factors for perception because they are at the very beginning of the causation chain of visual perception.

The ecological approach emphasizes the mutuality of the animal and the environment (Gibson 1979, 8). Unlike the world of physical reality, the world of ecological reality consists of meaningful objects and events. However, the meanings of perception are not signs, but "affordances". This means that properties of objects are meaningful to the observer without recourse to previous experience, for instance, the graspability and

Mirador Mayan site in Guatemala] you can see Calakmul (a Mayan site in Mexico)'. [https:// lt.wikipedia.org/wiki/El_Miradoras]. However, this verb is very rarely used in Lithuanian. 
throwability of a stone. The basic affordances of the environment "are usually perceivable directly, without an excessive amount of learning". A path affords pedestrian locomotion and a shelter affords protection from rain and snow. Put differently, it is immediately obvious what a path or a shelter are good for; no learning is required to realize this. Rock, however, pursues an entirely different argument for downplaying the relevance of experience for perception. According to him, processing in perception always starts without contact with stored memory since it is "only on the basis of similarity between what is now perceived and what had been perceived that recognition can occur" (Rock 1983, 307).

For Gibson, perception is not a passive response to a stimulus but an act of information pickup (Gibson 1979, 56-57). For Rock it is not passive either, but rather a thought-like cognitive process of problem solving that entails reasoning and taking decisions (Rock 1983, 339). For Gibson, direct visual perception is the activity of getting information from the ambient array of light. By 'information' Gibson does not mean signals transmitted from a sender to a receiver, but what can be extracted from a flowing optic array (Gibson 1979, 63), which is structured and changes over time. "The perceiver extracts the invariants of structure from the flux of stimulation while still noticing the flux" (Gibson 1979, 247). Information pickup "is a continuous act, an activity that is ceaseless and unbroken” (Gibson 1979, 240).

Gibson $(1966,47)$ conceives of the senses as active perceptual systems rather than passive conveyers of mere sensory quality (and also Rock speaks of the visual system). Natural vision depends on a complete visual system not only consisting of eyes, but also of a turning head and a moving body. The listening system "includes two ears together with the muscles orienting them to a source of sound" (Gibson 1966, 75). Smelling and tasting are defined by their functions in use. Tasting is pickup of all the available information about an object in the mouth including the sapid component, but also odor stimulation in the olfactory cavity, relative temperature, surface texture and consistency, shape, size, specific gravity and the condition of wholeness or granularity which makes tasting come very close to touching (Gibson 1966, 138). The function of smelling is to evaluate and identify the source of the odor and to orient and control behavior, including locomotion, with respect to the source (Gibson 1966, 146). The haptic system is not just the sense of skin pressure. Rather the layout of surfaces is perceived through co-variation of skin sensitivity and 
joint sensitivity, where different kinds of receptors combine in one system to register one kind of invariant information (Gibson 1966, 114). All this implies that perceiving is not just experiencing stimuli momentaneously, but can be as much an accomplishment or a process as an inceptive state. This is illustrated in examples (10) and (11).

Example (10) from Latvian is from the very end of the Brothers Kaudzìte's famous novel Mèrnieku laiki; the girl Annuža realizes that her beloved godmother is dead when she goes to visit her. There are three occurrences of the base raudzit 'watch' in this passage. Firstly, there is iet un apraudzit 'go and around-watch', i.e. 'go and visit', which initiates the explorative sequence with ambulatory vision. Secondly, the next form, ieraudzijusi, is inchoative only if considered in isolation. The girl 'starts' seeing all the people in the cottage. However, catching sight is directly connected to the preceding movement of entering the sauna cottage where the godmother lived. So, in a wider sense, it can also be considered the endpoint of ambulatory explorative vision. Inside the cottage, ambient vision continues and the second occurrence of specific 'see' ieraudzija is clearly the endpoint of the exploratory sequence.

(10) Latvian (Brāli Kaudzītes, Mērnieku laiki, 3,7, www.korpuss.lv/klasika/Senie/Kaudz/BK0307.htm) [Viņa bij padarïjusi veikḷi savus dienvidu darbus, atprasijusies saimniecei,]

lai ațauj iet un apraudzìt veco HORT allow.PRS.3 go.INF and visit.INF old.ACC.SG.DEF krustmāti, godmother.ACC.sG [kuru mìlēja vairāk par visu.] Ienākusi un ieraudzijusi

in.come.PST.PA.NOM.SG.F and see[SPEC].PST.PA.NOM.SG.F pirtināa tik daudz cilvēku sauna.DIM.LOC.SG so many people.GEN.PL [kā nekad un to vidū arì mācìtāju, vina iztrūkās, un jautrums bij piepeši izzudis no sejas.]

Vina skatijās apkārt, it kā kaut ko

3.NOM.SG.F look.PST.3.RFL around as how some what.ACC meklēdama, lìdz ieraudzija veco search.CVB.SG.F until see[SPEC].PST.3 old.ACC.SG.DEF 
krustmāti guḷam

godmother.ACC.sG lying.PRs.PP

[mierīgi ar saliktām rokām un aizdarītām acīm.]

'[She had done all her noon work and asked the landlady] whether she could go and see her old godmother, [whom she loved more than anything.] When she entered the cottage and saw so many more people [than ever and among them also the pastor, she got frightened and all gladness suddenly vanished from her face.] She looked around as if searching for something until she saw the old godmother lying [quietly with folded hands and closed eyes.]'

Vision is often following a moving object (pursuit movement, Gibson $1979,213)$, which is rather an activity than a state. Interestingly, pursuit is usually expressed with non-specific seeing verbs. In (11) from Lithuanian matyti 'see [NSPEC]' expresses a pursuit eye movement. Joris Globys is lying in bed in hospital after having lost a leg because he saved a girl from an approaching train. The girl is now visiting him, and he follows her with his eyes as she jumps up to the door in order to identify a source of noise.

(11) Lithuanian (J. Aputis, Skruzdèlynas Prūsijoje 84)

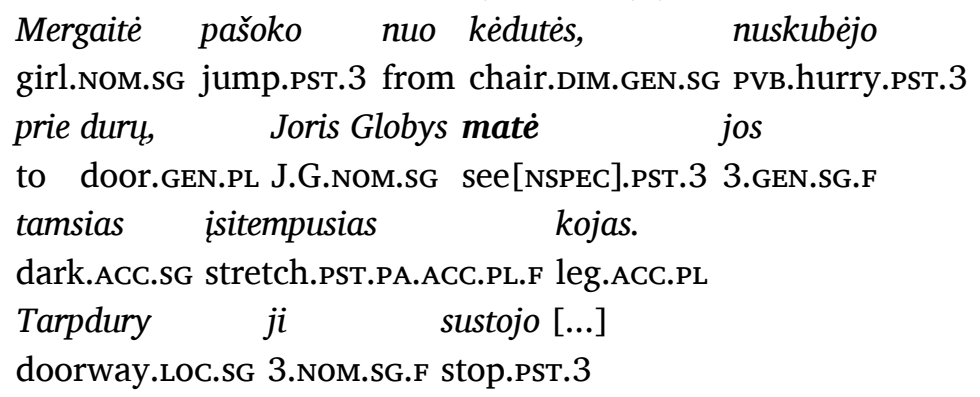

'The girl jumped up from the chair, hurried to the door. Joris Globys saw her dark and stretched legs. In the doorway she stopped.'

The non-specific 'see' is used here, and 'see' is obviously not a state here; mate 'saw' could be replaced by seke 'followed', which is clearly an activity (and note that the Germanic verb see is cognate with this verb and originally means 'follow'). The non-specific form is used, among other things, because Joris Globys has seen these stretched legs already 
before she jumped up in (11), notably when she ran toward the approaching train and he saved her. A further reason motivating the non-specific 'see' is that perception is not part of the sequence of events, but only concomitant and hence not determined within the chain of events.

For vision and touch, the notion of scanning, that is, sequential successive looking or touching, is highly important. We explore constant objects by scanning (successive sampling), but scanning is equivalent to simultaneous grasping. The environment we look at by scanning seems to coexist phenomenally although it has been looked at sequentially (Gibson 1966, 252). Our eyes can fixate, but have to jump about in order to explore, which allows us to follow a moving object in the environment, i.e. to track it with the gaze-line. If the exposure period is not very short, the eye will never stay still and scan the pattern to which it is exposed (Gibson 1979, 1). Verbal expression of scanning is illustrated in (12) from the same Lithuanian story by J. Aputis.

Joris' dying mother sees Joris' wife for the first time. With some help she gets up from her bed in order to be able to look at Tekle (and she insists that she has to get up for that). The 'looking' is part of the larger event of 'seeing' in the sense of meeting and is expressed with a nonspecific perception verb, as seeing in the sense of meeting is no new information pickup when the more specific visual exploration of the daughterin-law starts which is expressed by a sequence of explorative perception verbs and motion verbs. The last explorative verb in the sequence žvelge [look.PST.3] is actually not in any way active or explorative, it just specifies that there is a direction to an object that is of no interest for information pickup and it is combined with a negated present participle of regeti 'see[NSPEC]', which does not express that the mother has no retinal picture, but rather that she is not engaged in visual exploration any more, since she is exhausted and has now obtained enough visual information to come to a conclusion. ${ }^{14}$

(12) Lithuanian verbs of vision in action (J. Aputis, Skruzdelynas Prūsijoje 83)

Pasikèlusi ji ilgai žiūrëjo
PVB.RFL.rise.PST.PA.NOM.SG.F 3.NOM.SG.F long.ADV look.PST.3

\footnotetext{
${ }^{14}$ Regèti 'see[NSPEC]', the less common verb for 'see' in modern Lithuanian, has the connotation of seeing as an ability.
} 
i Teklę, nes matè ja pirmasyk.

in T.ACC because see [NSPEC].PST. 3 3.ACC.sG.F first_time

Pirmiausiai ji jž̆ambiu žvilgsniu

first.ADV 3.NOM.sG.F oblique.INS.sG glance.INS.sG

nužiūrèjo jos kakta, paskui

down.look.PST.3 3.GEN.SG.F front.ACC.sG then

nužvelgé akis, lūpas, ilgai klaidžiojo

down.look.PST.3 eye.ACC.PL lip.ACC.PL long.ADV err.PST.3

ties gražia ir neramiai

right beautiful.INs.sG and not.quiet.ADV

alsuojančia krūtine, paskui

breathe.ITER.PRS.PA.INS.SG.F breast.INS.SG then

nusileido prie jos keliu, ant

down.RFL.let.PST.3 at 3.GEN.SG.F knee.GEN.PL on

kuriu Tekle laike padejusi

which.GEN.PL T.NOM.sG hold.PST.3 PVB.lay.PST.PA.NOM.sG.F

rankas. Po to, matyt, pavargusi,

hand.ACC.PL after that.GEN.SG.M see.INF PVB.tire.PST.PA.NOM.SG.F

nieko neréginčiom akim

nothing.GEN not.see [NSPEC].PRS.PA.INS.PL eye.INS.PL

žvelge il aprūkusia krosnį ir po

look.PST. 3 in rust.PST.PA.ACC.SG.F oven.ACC.sG and after

kurio laiko

which.GEN.SG.M time.GEN.SG

[ištaré: -Tavo žmona yra graži, Jori. Tau per graži. Ar tu žinojai?]

'After getting up she looked at Teklè for a long time, for she saw her for the first time. First she looked with a sidelong glance at her front, then examined her eyes and lips, wandered for a long time over her beautifully and unevenly breathing breast, then went down to her knees, on which Teklè was holding her hands. After that she was apparently tired and stared at the rusty oven with empty eyes and [said] after a while: [-Your wife is beautiful, Joris. Too beautiful for you. Did you know that?]'

The most state-like vision in (12), staring at the oven, is actually expressed by a supposedly active explorative perception verb žvelgti 'glance'. 
The eyes are never static when seeing. However, the beholder has the "experience of a stable visual world" (Gibson 1979, 222) and that is where the state character of seeing comes from. What we see is not how our eyes move around in saccadic eye movements and in scanning, but persistence in the environment. It does not matter so much what is on our retinas at a given moment, but whether we perceive of the environment as persisting or changing. " $[\mathrm{T}]$ he structure of the ambient array is quite stable" (Gibson 1979, 222). Perception is not based on a sequence of discrete images, but on "invariance in a flow of stimulation" (Gibson 1979, 221). "[A] stationary and permanent environment is specified along with a moving observer" (Gibson 1979, 126) where exteroception (perception of the environment) is always accompanied by and not separated from egoreception (perception of self) (Gibson 1979, 126).

The experience of a stable world means that the temporality of perception is largely determined by exposure. Given the importance of persistence and change in the environment for information pickup, exposure period (Gibson 1979, 1), and how it relates to the perception period, is crucial for the semantics of perception verbs. Perception period in vision is not the time an object is depicted on the retina. The perception period is not ended by a blinking and often not even by longer inattentiveness such as sleep.

In example (13) from a Lithuanian story by Juozas Aputis, Benutis is asleep while recovering from an injury. When he awakes, he realizes that the dog is not under the table any more, but he hears him barking outside. Both seeing and hearing in (13) are about information pickup of a change in the environment (that is, both are equally inceptive), but the first one is expressed by a non-specific verb and the second one by a specific one. This suggests that it cannot be true that non-specific verbs just express states and specific verbs just express achievements.

(13) Lithuanian (J. Aputis, Prieš lapų kritima 40)

Šuniuko po stalu irgi nemate.

dog.DIM.GEN.sG under table.INS.SG also NEG.see [NSPEC].PST.3

Išgirdo, kaip jis sulojo prie

hear [SPEC].PST.3 how 3.NOM.SG.M PVB.bark.PST.3 at

būdos ir nutilo

kennel.gEN.sG and fall.silent.PST.3

'[When he woke up, the father was still in bed. The mother was 
already gone...] He did not see the dog under the table either. He heard how it barked near the kennel and then fell silent.'

An aspect theory that treats perception verbs like any other verbs, such as Vendler's, assumes that perceiving is determined in time by the perception period (as doing is by the activity period). However, in opportunistic perception verbs, the focus is on the opportunity, or put differently, on the exposure period, and exposure period is unique for perception; it does not occur in other kinds of events. As Rock (1983, 339-340) puts it, "perception differs from thought primarily because it is rooted in and constrained by the necessity of accounting for the proximal stimulus". Specific perception verbs express restricted opportunities for perception. In (13) there is a restricted opportunity for hearing the dog barking, but there is no restricted opportunity for seeing the dog, actually no opportunity for seeing the dog at all, since the dog is not there any more. Therefore, even though Benutis notices-starts realizing - that the dog is not there any more, no specific verb is used here.

There are undoubtedly examples where specific 'see' and 'hear' are in some way inchoative as in (14) from the Parable of the Prodigal Son where the elder son, returning from the field, starts hearing the music of the feast and continues hearing that music as the story goes on. However, for information pickup what is relevant in (14) is the recognition of a certain social activity (in Rock's sense, this is the perceptual problem to be solved here) in a context of ambulatory perception. Once the problem is solved, perceptual constancy is achieved on a higher level of perception, even though music and dance is by definition never static. Approaching a source of sound or vision determines exposure. Hence the onset of exposure is often highly restricted in ambulatory hearing and vision. There is a certain point on the journey where the music starts being audible.

(14) Lithuanian: information pickup begins at exposure (Mark 15:25) [Kai griždamas prisiartino prie namu,]
išgirdo
muzika
ir šokius.
hear[SPEC].PST.3 music.ACC.SG and dance.ACC.PL
'[when he came and approached the house,] he heard music and dancing' 
There are also many cases where specific 'see' and 'hear' do not express the onset of information pickup. Hearing is often hearing words and there is usually only one opportunity to hear words (or occasionally two if a word is repeated). In (15)—similarly as in example (1) above- 'hear' is used at first non-specifically for hearing that somebody is talking-and there is an extended unspecific period of opportunities to hear this flow of speech-but for hearing the message expressed by words, the same flow of speech is a more restricted opportunity for perception and hence for the words picked up the specific verb is used. The higher-level perception expressed by the specific verb is more holistic and it is more difficult to achieve.

(15) Lithuanian: non-specific and specific 'hear' (J. Aputis, Prieš lapu kritima 27-28)

...paskui Benutis girdi,

then Benutis.NOM.sG hear [NSPEC].PRs.3

[kaip su jomis ta pačia nesuprantama kalba šnekasi motina...]

tik išgirsta tos moteriškes žodžius:

only hear [SPEC].PRS.3 that.GEN.SG woman.GEN.SG word.ACC.PL "Bombit, bombit..."

'...then Benutis hears [how the woman talks to them in this same incomprehensible language...] he hears only those words said by the woman "bombit", "bombit".'

In (16) the boy Benutis realizes that he sees Helena for the last time. The situation is one single opportunity for having this feeling and the two uses of the same form for feeling in (16) refer to this very same event. Feeling, even though occurring at the same time, is not synchronized with seeing. Seeing has started already when feeling comes in. Although both seeing and feeling apply to the same situation, seeing is construed non-specifically as an extended sequence of opportunities and feeling as a single opportunity.

(16) Lithuanian: specific 'feel' and non-specific 'see' for the same situation (J. Aputis, Prieš lapų kritima 20)

...jis pajunta, kad jau tikrai

3.NOM.SG.M feel [SPEC].PRS.3 that already certain.ADV 
paskutinį sykį mato Helena,

last.ACC.sG time.ACC.sG see[NSPEc].PRs.3 Helena.ACC

pajunta labai aiškai ir paprastai...

feel[SPEc].PRs. 3 very clear.ADV and simple.ADV

'...he felt that he saw Helena for the last time, felt it very clearly and simply.'

Example (16), as example (1), illustrates a lower-level perception expressed by a non-specific verb feeding into a higher-level perception expressed by a specific verb. Interestingly, 'feel' is often used for a higherlevel perception of unconscious source not restricted to a single sense modality. There is nothing particularly tactile about 'feel' in (16). Perception cannot always easily be separated from other cognitive processes, and as Rock (1983, 339) argues, it is thought-like as it entails reasoning and taking decisions. However, what makes perception differ from other kinds of cognition is its being constrained by the necessity of accounting for the phenomenon exposed. As Rock (1983) puts it, perception is problem solving starting with a literal percept and searching for a solution with stimulus conformity (Rock 1983, 118). In this sense, 'feel' in (16) is as much perception as cognition.

Inceptive perception, viz. the synchronization of the beginning of exposure and perception period, is just one of many different kinds of restricting the exposure period, but it is not the most restrictive one. The importance of restricted exposure for specific perception verbs is most manifest in cases where there is no actual perception period at all and where all there is is restricted exposure. This is often the case in negation, as can be illustrated with a very bad joke in Lithuanian (17):

(17) Lithuanian: restricted exposure time specifying lack of information pick up (http://webcache.googleusercontent.com/ search?q= cache:gZNmaRIXx3gJ:pazintys.draugas.lt/srautas. cfm\%3Ftitle\%3DVaziuoja-blondine-automobiliu-nepamatomedzio-trenkiasi-Is-umai\%26irasas\%3D191095 + \&cd $=1 \& \mathrm{hl}=$ en\&ct $=\operatorname{clnk\& gl}=\mathrm{se}$ )

Važiuoja blondine automobiliu, nepamato

drive.PST.3 blonde.NOM.SG car.INS.SG NEG.See [SPEC].PRS.3

medžio,

tree.GEN.SG 
[trenkiasi. Iš sumaitotos mašinos iššliaužia visa kruvina ir sako: — Bet aš juk pypinau.]

'A blonde is driving. She does not see the tree [and collides. She saves herself out of the destroyed car all bloody and says: —But I tooted.]'

In (17) there is just one single opportunity to see the tree before the crash. After that moment has passed, it is too late to react appropriately to the affordance of the tree. Example (17) shows that negation does not always go together with non-specificity in Lithuanian. In cases of missed opportunities (often due to difficult conditions), specific perception verbs are clearly preferred in negation. Negation also illustrates that specific perception verbs are in a sense more informative than non-specific ones, since specific perception verbs, to the extent they emphasize restricted exposure, presuppose an opportunity for perception, whereas non-specific perception verbs do not presuppose an opportunity for perception.

Given that non-specific verbs express restricted exposure, they can be used as a rhetorical device to evoke uniqueness of opportunity as is common in travel ads, such as (Lithuanian) Top $10 \mathrm{ka}$ galima pamatyti [see[sPEc].INF] Australijoje 'The top 10 that can be seen in Australia' or in a sequence of imperatives-another non-factive context where there is no actual perception period-where the specific sequence reinforces the restrictedness of the exposure (a book title):

(18) Lithuanian: Specific 'feel' and 'see' both in one sequence construed as unique opportunities in an add

(http://www.sena.1t/zodynai_zinynai/peciuliene_ona-pajusk_ lietuva_aplankyk_pamatyk_dalyvauk_paragauk/607133)

Pajusk Lietuva. Aplankyk,

feel [SPEC].IMP.2sG Lithuania.ACC visit.IMP.2sG

pamatyk, dalyvauk, paragauk

see [SPEc].IMP.2sG, participate.IMP.2sG, PVB.taste.IMP.2sG

'Feel Lithuania! Visit, see, participate and enjoy!'

While terrestrial events are usually very hard to predict, this is not true for certain celestial events, which are fully predetermined in their uniqueness. Russian has few contexts where the semantics of specific verbs does not somehow interfere with the grammar of aspect (see Section 7). But one of them is the infinitival complement of potential modal 
verbs. In such a construction as (19), specific verbs are most predictable if they refer to predetermined celestial events:

(19) Russian: Restricted exposure in a predetermined celestial event (http://gikursk.ru/news/4305/)

Segodnja žiteli Kurska mogut

today inhabitant.NOM.PL Kursk.GEN can.PRS.3PL

uvidet' solnečnoe zatmenie

see [SPEC].INF solar.NOM/ACC.SG eclipse.NOM/ACC.SG

'Today the inhabitants of Kursk can see a solar eclipse.'

Exposure can be restricted not only temporally, but also by bad conditions, such as poor illumination as in (20).

(20) Latvian: bad conditions for vision (R. Blaumanis, Paradize, www.korpuss.lv/klasika/Senie/RBl/RBl0114.htm):

[«Lidī̌su zem gultas,» Andžs izmisis sacïja, «kas zin, viņš manis tur nepamanīs.»

«Kā pa durvìm nāk, tā tūlìt var redzēt, kas zem gultas,» Ieva tikpat izsamisuse atteica.]

Andžs apskatijās vēlreiz visapkārt.

A.NOM.sG around.look.PST.3.RFL yet.time all.around

[«Kas tas?...»Viñš ieskrēja vienā kaktā, kur prāva lāde stāvēja, kuru viņš_vai nu aiz bailēm,]

vai aiz tauku sveces vājās

or behind fat.GEN.PL candle.GEN.SG weak.GEN.SG.DEF

gaismas- lidz šim nebij

light.GEN.sG until this.DAT.sG NEG.be.PST.3

ieraudzījis.

See [SPEC].PST.PA.NOM.SG.M

'["I will crawl under the bed", Andzhs said in desperation. "Who knows, maybe he will not see me there" "If one enters by the door, one can see immediately what is under the bed", Ieva answered equally desperate.] Andzhs looked around once more. ["What's that?..." He ran to a corner where there was a simple box which] he had not seen until now, [maybe because he was frightened,] or maybe because of the weak light of the oil candle.'

The consequence is that specificity is not primarily a matter of lexical aspect - which is a feature of all events, not only of perception events- 
but notably a matter of conditions of perception-and these are domainspecific. This leads us to the relevance of obscured perception verbs, which emphasize difficult conditions, to be treated in the next section.

\section{Obscured perception verbs in Baltic and Russian}

Under ideal conditions perception is effortless and immediate. However, conditions are not always good. The beholder may have bad eyesight, an object may be far away or it may be dark. Sound may be faint, and speech quiet or mumbled. Under such impoverished conditions (Rock 1983, 307) it takes effort to pick up information if perception can be achieved or accomplished at all and there is also a risk of misrecognitions.

Difficulty of perception figures rarely as a factor in the literature on perception verbs. A notable exception is Faber \& Pérez $(1997,76)$ who point out its relevance along with partial vision and distance of the perceptual object and argue that it is often combined with momentary visual perception as in English spy, glimpse, spot and sight and in Spanish divisar, avistar, atisbar, vislumbrar, entrever and guipar. Referring to Faber \& Pérez, Paducheva (2004, 215) identifies a large number of Russian verbs for which the notion of zatrudnennoe vozprijatie ('perception with difficulty') is relevant. The group of verbs considered in this section is narrower; explorative verbs, such as issledovat' 'explore', are not considered.

The Baltic and some Slavic languages including Russian have dedicated obscured perception verbs for the expression of perception under difficult conditions. In Latvian (including Latgalian) they are formed with the prefix sa- 'together':

(21) Latvian: obscured vision with occluding edge (A. Deglavs, Rigga, I,1,1, www.korpuss.lv/klasika/Senie/ADegl/ADa0101.htm) [«Labi vajag atmest galvu,]

lai varētu saredzēt jumtu...

HORT can.IRR see [oBSC].INF roof.ACC.SG

'[It is necessary to bend the head strongly backwards] in order to see the roof...'

(22) Latvian: obscured vision with high distance and perhaps also occluding edge (A. Deglavs, Rìga, I,1,1, www.korpuss.lv/klasi$\mathrm{ka} /$ Senie/ADegl/ADa0101.htm)

[«Pētera baznicas tornim, apakšā stāvēdams,] 
galu gandriz nemaz nevar saredzēt...

end.ACC.sG almost absolutely NEG.can.PRS.3 see [oBSc].INF

'[Standing under the tower of St.Peter's Church] you can barely see the top...'

(23) Latvian: obscured vision with bad eyesight and poor illumination (Brāḷi Kaudzītes, Mērnieku laiki 2,5, www.korpuss.lv/klasika/Senie/Kaudz/BK0205.htm)

[Annuža ar savām vecām un patumšām acīm pie vājas skala gaisminas]

gan nedabūja ienācējas nemaz saskatit PTC NEG.get.PST. 3 incomer[F].GEN.SG absolutely look [oBSC].INF '[Annuzha with her old and blurred eyes] could not see the woman coming in [in the weak light of the pine chip.]' (Annuzha has perceived that the door opened and somebody came in and fell down, but she cannot see the person.)

In (22) the obscured 'see' verb expresses distance, among other things, and in Section 3 we have seen that some languages such as Mandinka and Tagalog have specific verbs for 'see from a distance' which are functionally closely related to obscured 'see' verbs.

Interestingly, Latvian obscured perception verbs can either be formed from opportunistic bases (redzēt 'see' in (21-22)) or from explorative bases (skatit 'look' in (23)) almost without any difference in meaning. There seem to be individual preferences. For instance, in the novel Rēgi, V. Kaijaks uses only explorative bases—saklausit 'listen[oBsc]' and saskatit 'look[oвsc]'-but not sadzirdèt 'hear[oвsc]' or saredzèt 'see[oвsc]'.

As examples (21-23) show, obscured perception verbs tend to be combined with potential modal verbs, ${ }^{15}$ but they express possibility even by themselves if there is no explicit modal verb (see below for examples). Present passive participles are known for their modal meaning, so it is not unexpected that the present passive participles of obscured 'see' and 'hear' (saredzams, sadzirdams) often occur with potential modal meaning.

Obscured perception verbs are mostly used when perception is only barely successful or not successful due to difficult conditions. An obscured perception verb combined with an adverb such as 'clearly' usually expresses a poorer perception demanding more effort than the bare opportunistic verb:

${ }^{15}$ For a discussion to what extent Latvian dabūt is modal see Daugavet (2015). 
(24) Latvian obscured perception verb with 'clearly' (Brāḷi Kaudzītes, Mērnieku laiki, 3,1, www.korpuss.lv/klasika/Senie/Kaudz/ BK0301.htm)

[Šì valoda izplatījās ātri no mutes uz muti, un drīz viṇu runāja visa drūzma gandriz jau pilnā balsī vai vismazāk tā,]

ka Liena varēja visu to skaidri

that Liena.NOM.SG can.PST.3 all.ACC.SG that.ACC.SG clear.ADV sadzirdèt.

hear [oBsc].INF

'[This message spread quickly from mouth to mouth and soon the whole crowd pronounced it almost in full voice or at least in such a manner] that Liena could hear all this clearly.'

While the Latvian preverb sa- 'together' emphasizes the recollecting effort during the attempt for information pickup, Russian uses the semantically opposite prefix raz- 'apart' emphasizing the discriminating effort. For vision there are explorative base verbs (razgljadet', rassmotret'), for 'hear' the opportunistic base verb is preferred (rasslyšat'). Lithuanian has obscured 'see' verbs with an explorative base (jžiürèti, also jžvelgti), but for hearing, there is no special verb. Rather išgirsti 'hear[SPEC]', the specific opportunistic perception verb, is used. The following Russian example from Bulgakov's novel Master i Margarita with its Latvian and Lithuanian translations from the Parasol corpus (von Waldenfels 2006, 2011) illustrates obscured 'hear' and 'see' from the three languages. ${ }^{16}$

(25) Russian obscured 'hear' and 'look' (Bulgakov, Master i Margarita) [i prislušalsja—v komnatax moix igral patefon. Èto vse,]

čto ja rasslyšal. No razgljadet'

what I.NOM hear [oBSc].PST.M.sG but see [oBSC].INF

ničego ne mog.

nothing.GEN not can.PST.M.SG

'[and listened-a gramophone was playing in my rooms. That was all] I heard, but I could not see anything.'

\footnotetext{
${ }^{16}$ No obscured verbs are used in the translations to English, German, Dutch, French, Italian, Spanish, Portuguese, Romanian, Slovene, Serbian-Croatian, Bulgarian, Czech, Estonian, Hungarian, and Esperanto. Perfective verbs are used in the translations into Belarusan (pačuć, ubačyć), Ukrainian (nasluxaty, dobačyty), Polish (usłyszeć, zobaczyć), and Slovak (počut)
} 
(26) Latvian obscured 'hear' and 'look' (Bulgakov, Master i Margarita) [un ieklausijos - manās istabās spēlēja patafons. Tas bija viss,] ko sadzirdēju. Bet saskatit what.ACC hear [oBSC].PST.1.sG but see [oBsc].INF nevarēja nekā. NEG.can.PST.3.sG nothing.GEN

(27) Lithuanian obscured 'hear' and 'look' (Bulgakov, Master i Margarita)

[ir isiklausiau—mano kambariuose grojo patefonas.]

Tiek ir teišgirdau, bet ničnieko that.much also RSTR.hear [SPEC].PST.1sG but nothing.GEN neistengiau ižiūrèti. NEG.arrive_at.PST.1sG look [oBSc].INF

Lithuanian can be said to distinguish less neatly between obscured and specific perception verbs, but also in Russian and Latvian the distinction is not always neat. Sometimes specific verbs are used with obscured meaning and sometimes obscured verbs are difficult to distinguish from specific verbs. The former is illustrated in (28) from J. Kazakov's short story Arcturus the Hunting Dog:

(28) Russian obscured 'hear' expressed by perfective 'hear'

(J. Kazakov Arktur—gončij pes, 3)

I ešče on slyšal tončajšie

and still 3.NOM.SG.M hear.PST.SG.M fine.SUPER.NOM.PL.M

zvuki, kakix my nikogda ne

sound.NOM.PL which.GEN.PL we.NOM never not

uslyšim

hear [PFV].PRS.1.PL

'And he (the dog) heard the finest sounds, which we never can hear.'

The impossibility of using a verb prefixed with raz- in (28) makes clear that difficult conditions do not by themselves trigger the use of a dedicated obscured verb. In (28) the issue is not distinguishing between different percepts, but perceiving or not perceiving. As pointed out above, the prefix raz-emphasizes the discriminating effort. It has thus a function similar to English distinguish and Swedish urskilja 'distinguish'. An even closer match is Danish (and Norwegian) skelne 'distinguish'. What makes 
Danish skelne differ from the Baltic and Russian verbs discussed above is that it is unspecified as far as the perceptual system is concerned.

Sight is the discriminating sense par excellence. It is hence not surprising that Lithuanian has an obscured sight verb, but no dedicated obscured hear verb. Whenever difficult conditions are at stake and the discriminating effort is not emphasized, we find examples of specific verbs in Baltic even for vision, as illustrated in (29) for Latvian and (30) for Lithuanian.

(29) Latvian specific 'see' in obscured use (R. Blaumanis, Paradizē, www.korpuss.lv/klasika/Senie/RBl/RBl0114.htm)

[«Viña dievgaldnieku tā bij pārpildìta, ka es tai drūzmā]

neviena pazistama gimima nevarēju

no.GEN.sG.M known.GEN.sG.M face.GEN.SG NEG.can.PST.1sG

ieraudzit. Pat tavas Annas, kuru no

see [SPEc].INF even your.GEN.SG.F Anna.GEN which.ACC.sG from

cepures vienmēr lēti uzeju, šoreiz

cap.GEN.sG always cheap.ADV find.PRs.1sG this.time

nevarēju ieraudzit.

NEG.can.PST.1SG see [SPEC].INF

'[It (the church) was so overfull with churchgoers that I] couldn't see a familiar face [in this swarm]. I couldn't even see your Anna whom I always easily recognize from her cap.'

In (30) from a science fiction story, 'see' is used with the continuative prefix be- (Arkadiev 2011a) in a context which does not lend itself easily to a totality interpretation. However, the specific verb emphasizes here that the continuation was minimal with highly restricted exposure and very rapid deterioration of the visual conditions. ${ }^{17}$ It is not entirely clear which use of be- applies to (30); probably the 'low degree' use (Arkadiev 2011a, 46).

(30) Lithuanian specific 'see' in obscured use

(http://www.rasyk.lt/kuriniai/67783.html)

Pinčius su seneliu tik bepamate, kaip

P.NOM with old.man.INS.sG only CNT.see [SPEC].PST.3 how

\footnotetext{
${ }^{17}$ In this context it may be relevant to add that forms of 'see' are lexicalized with the continuative/progressive prefix for the expression of immediateness: bemat, bematant [cNT.see. PRS.PA], beregint [CNT.see.PRS.PA] 'immediately'. Among the uses of be- listed in Arkadiev (2011a, 44-46) the progressive use fits best (non-finite form expressing "ongoing background situation").
} 
jis pavirto i maža juoda

3.NOM.SG.M PVB.turn.PST.3 into small.ACC.sG black.ACC.sG taškelį ir greitai visai išnyko iš akių. dot.DIM.ACC.sG and quickly fully disappear.PST.3 from eye.GEN.PL 'Pinčius and the old man only saw how he turned into a small black dot and soon completely disappeared from eyesight.'

Sometimes specific and obscured perception verbs occur side-by-side. Example (31) is from an information page about prenatal ultrasound diagnostics. An ultrasound session is a specific opportunity to see something that cannot be seen normally (restricted and predetermined exposure time). Hence the use of a specific perception verb is appropriate-in Lithuanian even in a habitual context as in (31). The specific verb is used for what generally happens in the specific context, the obscured verb is used in the more discriminating one of the two contexts.

(31) Lithuanian

http://www.tavovaikas.lt/nestumas/2-nestumo-trimestras/kasvarbu-zinoti-apie-ultragarsini-tyrima.d?id = 63771692

[Tèvai džiaugiasi,]

kad gali pamatyti kūdikèlį aiškiau, that can.PST. 3 see [SPEC].INF baby.DIM.AcC.SG clear.coMP.ADV iš arčiau. Kartais pasiseka from close.comp.ADV Sometimes PVB.RFL.succeed.PRs.3 ižvelgti net vaikučio veido bruožus. see [oвSc].INF even child.DIM.GEN.SG face.GEN.SG trait.ACC.PL '[The parents are happy] when they can see the baby clearer, more closely. Sometimes it is possible to distinguish even the facial features of the little child.'

In Russian obscured perception verbs are always perfective. The imperfectives razgljadyvat' and rassmatryvat' 'leaf/thumb through' have different meanings and are not obscured perception verbs.

While perception is immediate under ideal conditions, it can take a while under difficult conditions. Sometimes only a very short while, which can then be expressed by adverbs such as 'immediately'. In V. Kaijaks' Latvian novel Rēgi there are such examples as ātri saskatija [quickly see[oвsc].pst.3] 'saw quickly', or: 
(32) Latvian: obscured perception taking time (Kaijaks 1993, 39):

Arvien skaidrāk saskatija,

always clear.comp.ADV see [oBsc].PST.3

[ka vina jaunības pilsēta stāvēja pasaules lielceḷa malā kā ubadze ar izstieptu roku]

'He saw more and more clearly [that the city of his childhood stood at the border of the world's highway like a beggar with her outstretched hand.]'

Given that specific perception verbs used for difficult conditions are accomplishments rather than achievements and given that specific perception verbs often have an explorative base (Latvian raudzit 'watch, look' in ieraudzit 'see[sPEC]', German blicken 'glance' in erblicken 'see[sPec]', Serbian-Croatian gledati 'look, watch' in ugledati 'see[SPEC]'), it is not unlikely that obscured perception has played an important role in the diachronic development of at least some specific perception verbs. ${ }^{18}$ Notice that Latvian specific 'see' ieraudzit has the same morphological makeup as Lithuanian ì-žiürèti [in-look] 'see[oвsc]'. Note that while most German perception verbs with the prefix er-, such as erlauschen 'listen[oBsc]', ertasten 'touch[oвsc]', erschnuppern 'smell[oBsc]', erschmecken 'taste[oBsc]' are quite clearly accomplishments, the visual erblicken is rather a specific verb 'see[SPEC]'. The diachronic connection between obscured and specific perception verbs is a promising topic for further research.

But let us now turn to 'smell' where Latvian has the same verb for obscured and specific verbs: saost, as illustrated in (33).

(33) Latvian: obscured 'smell' verb (P. Süskind, Das Parfüm)

[...pastiepās uz pirkstgaliem, lai pāri ḷaužu galvām]

mēéginātu kaut ko saost,

try.IRR IDEF what.ACC smell [SPEC].INF

'[Every few strides he would stop and stand on tiptoe in order to] take a sniff [from above people's heads.] ${ }^{19}$

${ }^{18} \mathrm{P}$. Arkadiev points out to me that this development is expected based on our knowledge about how semantic change proceeds (more expressive $>$ less expressive).

${ }^{19}$ Actually the Latvian translation is rather free here, all other texts in the Parasol corpus have an explorative construal, as has the German original (um über die Köpfe der Menschen hinwegzuschnuppern). Lithuanian has a delimitative and iterative explorative form in the habitual past (pauostinedavo PVB.sniff.ITER.HAB.PST.3). 
In (33) it is formally not clear whether we have to deal with an obscured or a specific 'smell' verb, but it is very clearly an accomplishment in conative use and the effort it takes to smell is emphasized. The use of the prefix sa- in the specific verb which is the same as used in obscured verbs might suggest that specific 'smell' in Latvian is always obscured. However, smell is the least discriminating of all senses. Odors mix and mask each other; it is difficult to smell two or more distinct odors at the same time (see Engen $1982 \mathrm{ch} .7$ on odor mixtures). It is therefore not unexpected that there is a hierarchy sight $>$ hear $>$ smell when it comes to dedicated obscured verbs. This hierarchy matches Viberg's sense modality markedness hierarchy at least if restricted to these three perceptual systems.

However, where exactly touch sorts in in the hierarchy of obscured verbs is more difficult to determine. Latvian has two verbs sajust and sataustit, the former is the same as the specific touch verb; sataustit is distinct due to its explorative base taustit 'touch'. However, taustit is rarely used for discriminating by touch, but primarily for finding something that the subject is looking for. The Russian original for (34) has našarit' [on-grope] with the same prefix na- 'on' as in na-jti [on-go] 'find'; another translation equivalent for Latvian sataustit is Russian na-ščupat' [on-touch/examine].

(34) Latvian: accomplishment 'taste' verb (V. Bulgakov, Master i Margarita)

Taustidamies gar sienām, Ivans ieraudzīja touch.cVB.sG.M.RFL along wall.DAT.PL Ivan.NOM See[SPEC].PST 3 gaismas strēliti zem durvim, light.GEN.SG streak.DIM.ACC.SG under door.DAT.PL sataustija rokturi touch [oвsc].PST.3 handle.ACc.sG [un ne visai stipri parāva.]

'Having bumped into the wall a few times, Ivan saw a faint streak of light under a door, felt for the handle, and pulled it gently.'

Whether or not sataustit in (34) is an obscured verb, it is certainly an opportunistic perception verb (it is like 'find' rather than 'search') and it is an accomplishment rather than an achievement as is characteristic for obscured perception. (Interestingly, German prefers the explorative verb 
in such contexts-tasten nach-whereas English has feel for, with an opportunistic lexeme, but the intransitive construction makes it explorative.)

Lithuanian can have dedicated verbs-apčiuopti, užčiuopti-but often has apgraibomis susirasti [touching.INs.PL find.RFL] 'find for oneself by touchings'. This makes it difficult to determine whether Lithuanian, where there is no dedicated obscured verb for hearing, may be counted as evidence for ranking touch above hearing in the hierarchy. Russian, where the prefix raz- is not used with touch, speaks against it.

We may conclude that that sight is clearly on top of the obscured verb hierarchy and smell on the bottom, whereas the position of hearing and touch with respect to each other is not yet entirely clear.

\section{Baltic specific perception verbs and verbal aspect}

\section{1. 'See' and 'hear' close to (im)perfective in Baltic, but irregular in Slavic aspect}

In Slavic languages specific perception verbs are mostly perfective. In Section 5 we have seen that this also holds for obscured perception verbs. This is reason enough for a look at the relationship between Baltic specific perception verbs and Slavic verbal aspect. Verbal aspect is one of the most frequently treated issues in Slavic linguistics. I will consider here only a few selected studies which take into account differences in the makeup of the aspect categories in different Slavic languages and which focus on different behavior of different verbs.

It may appear as a paradox that 'see' and 'hear' are among the verb domains with most strongly aspectual behavior in Lithuanian and Latvian while 'see' and 'hear' are at the same time among the most irregularly behaving verb domains in Slavic aspect. As shown in Section 3, the distribution of (non-)specific 'see' in Russian is a closer match to Lithuanian than to Czech and the South Slavic languages.

There are three kinds of approaches to Slavic aspect as far as the level of generality or locality of aspect distinctions is concerned: (i) global, (ii) verb-group, and (iii) local. As we will see later, these three need not mutually exclude each other. Especially the global and the local approach are highly compatible if viewed as perspectives rather than universal solutions.

The global approach considers the semantics of the (im)perfective distinction in general. Dickey (2000) follows this line and finds that im- 
perfective in eastern Slavic languages expresses qualitative temporal indefiniteness and in western Slavic languages quantitative temporal indefiniteness. In 6.2 we will see that Baltic specificity is closest to western Slavic on this global level.

The verb-group approach has been developed in different ways, among others, by Maslov (1948) and Breu (1980). Breu (1980, 17) calls it the lexical approach, but this name is misleading, as it is argued that large groups of verbs, such as perception and cognition verbs forming ingressive lexical pairs (see 2 vii above) display particular behavior. The verb group approach has to be distinguished from the local approach, as favored, for instance, by Bermel $(1997,128)$, who argues that Old Russian uvidětb 'see[PFv]' displays a clear difference in lexical content (a meaning closer to 'understand, grasp'). He claims that there is no single factor controlling aspectual assignment and function in Old Russian (Bermel 1997, 205L). A similar point has been made for 'see' and 'hear' in modern Russian by Lehmann (1989). Volker Lehmann shows that there are certain uses where videt' 'see[IPFV]' is possible whereas zamečat' 'notice[IPFV]' is not (Kogda oni proezžali mimo, oni videli/ "zamečali signal. 'When they passed, they noticed the signal') and concludes from this and similar examples that (u)videt' and (u)slyšat' display irregular aspectual behavior which he explains in diachronic terms.

This leads us to the question of how to deal with aspectually irregular verbs. Slavicists use the term biaspectual verb for verbs not distinguishing (im)perfective aspect. ${ }^{20}$ But it is not clear how anaspectual biaspectual verbs really are and whether they are a uniform class. Bunčić (2012) argues that Russian biaspectual verbs generally have a preference for either perfective or imperfective aspects. Generally, Slavicists do not seem to agree what exactly a biaspectual verb is. For instance, Schuyt (1990, 3738) follows Beaulieux (1950) for Bulgarian with a wider class of biaspectual verbs (including vidja 'see' despite the fact that there is also viždam 'see[IPFV]'), but for Macedonian he follows Lunt (1952) with a much more restricted list of biaspectual verbs, which wrongly suggests that Bulgarian has a larger class of biaspectual verbs than Macedonian. For Russian, however, where biaspectual verbs seem to be more restricted, one can

${ }^{20}$ This term is actually misleading. In his grammar of the New Guinean language Mian, Fedden $(2007,236)$ uses 'biaspectual' for verbs having an (im)perfective distinction and 'transaspectual (or aspect-neutral)' for verbs lacking an (im)perfective distinction. 
easily find claims such as that there is a "relatively large group of biaspectual verbs" (Piperski n.d.), which probably can be explained best by the fact that biaspectual verbs have been more investigated in Russian than in other Slavic languages. Claims that 'see' and 'hear' are biaspectual can be found for most South and West Slavic languages.

Put differently, there are global, verb-group and local approaches to 'biaspectual verbs' and other irregularities. The global perspective makes them appear anaspectual; Bunčić's (2012) approach divides them into two groups. However, the approach favored here for verbs with irregular behavior is that they should be addressed in local terms, for which lexical typology is a particularly suitable. The local approach is particularly important in Baltic, where there is very limited evidence for any global level (6.3). At the same time, however, the Baltic languages do not defy a comparison to Slavic on a global level (6.2) even though such a comparison abstracts away from the most crucial characteristics of Baltic specificity.

\subsection{On the global level Baltic specificity is closest to western} Slavic aspect

Dickey (2000) shows that aspect in western Slavic languages (Czech, Slovak, and Slovenian) displays a number of properties differing from aspect in eastern Slavic languages (Russian, Ukrainian, and Bulgarian), whereas he considers Polish and Serbian-Croatian to be transitional zones (see also, for instance, H. Galton 1976 and Holvoet 1993 for earlier related, but different work and von Waldenfels 2012 for more recent work based on parallel texts). Dickey $(2000,260)$ identifies fifteen East-West isoglosses of differences in habitual, general-factual, historical present, performative, sequential, phasal, and ingressive contexts and in verbal nouns, and suggests that the common denominator is a global semantic difference between perfective and imperfective. Perfective in the West expresses totality and in the East temporal definiteness (the latter following Leinonen 1982). Imperfective in the East expresses qualitative temporal indefiniteness (no assignment to a unique point in time) and in the West quantitative temporal indefiniteness (assignability to more than one point in time). However, nearly all of the isoglosses also point toward a higher paradigmatic integration of verb pairs in the East (and herewith a higher degree of grammaticalization of aspect). In the East only the imperfective can be used in habitual contexts and in historical present, and 
verbal nouns do not distinguish aspect. There are no such restrictions in the West.

To the extent specificity in perception verbs in Lithuanian is similar to aspect, it clearly patterns together with western Slavic, which does not mean anything else than that there are no strict grammatical restrictions in Baltic (see also Arkadiev 2011b, 71). Verbal nouns can be formed from both specific and non-specific verbs, and specific verbs are common in habitual/iterative contexts and in the historical present. (35) exemplifies a verbal noun with a specific verb in Lithuanian, where the totality of the event is emphasized, however, in a generic context.

(35) Lithuanian: verbal noun from specific perception verb (http://www.respublika.lt/lt/naujienos/pramogos/kinas_ muzika_tv/ar_smurtas_filmuose_daro_itaka_zmoniu_ veiksmams/,print.1)

[Kitas dalykas, jeigu vaikų ir tèvų tarpusavio ryšys yra labai tvirtas, vaikai nepatiria patyčiu mokykloje, jaučiasi saugūs,]

tad smurtinio filmo pamatymas

then violent.GEN.SG film.GEN.SG see [SPEC].ACN.NOM.SG

[jiems neturès didelès įtakos.]

'[Things are different if the mutual relationship between children and parents is very strong, if the children are not exposed to scorn in school and feel safe,] then the watching of a violent film [does not have a heavy impact on them.]'

Example (36) from the New Testament illustrates an iterative context (even though the perception verb itself is in a non-habitual form, given that it is a participle).

(36) Lithuanian (1998): habitual context (NT Mark 3:11)

[Taip pat netyrosios dvasios, ]

vos tik Ji pamačiusios,

barely only 3.SG.ACC.M see [SPEC].PST.PA.NOM.PL.F

parpuldavo

fall_down.HAB.PST.3

[priešais Jị ir šaukdavo: “Tu esi Dievo Sūnus!”]

'[And the unclean spirits,] whenever they saw him, were falling down [before him and crying out, saying, "You are the Son of God!']' 
As expected from the Dickey parameters, Russian, Ukrainian and Bulgarian have imperfective forms in the same passage (Russian videli 'see[IPFV].PST.PL') whereas Czech and Polish have perfective forms (Czech zazřeli 'see[PFV].PST.PL.M'). Interestingly, however, the Ukrainian form vbačaly 'see[SPEC/IPFV].PST.PL' is both specific and imperfective, demonstrating that specificity and perfective aspect are not necessarily always the same thing. Vbačaty (with the variant ubačaty) is an imperfective verb, morphologically a prefixed iterative. Iterative 'see' in Russian, vidat', is mostly used in experiential contexts such as nikogda ničego takogo my ne vidali [never nothing.GEN such.GEN.SG we.NOM not see.ITER.PST.PL] 'We have never seen anything like this!" (Mark 2:12), which has an interesting areal parallel in Mordvin where the same phenomenon can be observed: Erzya Mordvin ...ez'-in'ek n'e-kšn'e [NEG.PST-1PL >3 see-ITER. CONEG] '[We] have [never] seen [anything like this]!" (Mark 2:12).

The use of imperfective (and even iterative) in experiential and other kinds of perfect-like context in Slavic is unexpected from the point of view of such approaches to aspects that view perfective as events ${ }^{21}$ (A. Galton 1984; Löbner 1988). According to Löbner (1988, 177) an experiential perfect expresses the state after a transition where there are no events of the type $\mathrm{E}$ to a time where such events have taken place at least once $(\exists \mathrm{E})$. Experiential contexts are related to what Slavicists call the generalfactual imperfective which traditionally by Jakobson (1957) and others have been adduced as a proof for the hypothesis that the imperfective is unmarked and hence indifferent to the aspect distinction. ${ }^{22}$ Dickey (2000, ch. 3) rejects this view and argues that the imperfective in general-factual contexts rather shows that the eastern Slavic perfective expresses temporal definiteness (and this would be consistent with Löbner's approach since "there exists an event of type E" is indeed indefinite). However, the use of imperfective in experiential and other perfect-like functions is pervasive even in western Slavic languages and extends to non-specificity in Baltic languages:

(37) Lithuanian: non-specific perception verbs in experiential context (Mark 2:12)

"Tokiu dalyku mes niekad nesame
such.GEN.PL thing.GEN.PL We.NOM never NEG.be.PRS.1PL

\footnotetext{
${ }^{21}$ In the sense of abstract individuals and as opposed to states, which are properties of times. Note that 'event' and 'state' in A. Galton's sense differ from Vendler's use of the terms.

${ }^{22}$ See Grønn (2003) for a detailed treatment of the Russian factual imperfective.
} 


\section{mate"}

\section{See.PST.PA.NOM.PL.M}

'We have never seen anything like this!'

In Section 3 we have seen that existential uses of perception verbs are very low on the specificity cline. Among the languages considered, only Ossetic and Bulgarian use a specific verb in this context. The low degree of restrictedness of exposure of experiential perfects of 'see' and 'hear' is well in line with Inoue's (1975) view that experientials are repeatable and, as Dahl (1985) puts it, that the experiential "sentence must concern a generic activity, state etc., rather than an individual, or specific one" (Dahl 1985, 141).

We may conclude that specificity in Baltic perception verbs can be compared to aspect across Slavic, and that the Baltic languages pattern together with western Slavic languages, with which they share a lower degree of grammaticalization of the aspect distinction. Dickey's approach to Slavic aspect is compatible with the notion of specificity in perception verbs as outlined in this paper. The major difference is that specificity is a scale whereas imperfective and perfective in Slavic are usually considered to reflect an underlying binary semantic distinction. However, Dickey's notion of temporal definiteness lends itself to a scalar reinterpretation (more temporally definite or less temporally definite) whereas such a reinterpretation is more of a challenge for the notion of totality.

\subsection{Baltic specificity is local}

For Baltic, Arkadiev et al. $(2015,35)$ argue that "despite important differences between Slavic and Baltic in the domain of expression of aspectual distinctions, there is no difference of principle, rather a difference of degree of grammaticalization." Baltic shares with Slavic the productive derivation of verb stems by prefixes and suffixes. The important differences lie (i) in the pervasiveness and (ii) in the degree of grammaticalization.

(i) Pairs of stems acquired by derivation do not pervade the stock of verb stems. There is a large and heterogeneous class of verbs which cannot be ascribed to an aspect (to put it differently, the class of biaspectual verbs is very large and comprises many basic and frequent lexemes; see Arkadiev 2011a). This point is not particularly important for opportunistic perception verbs, since there are pairs of perception verbs throughout all sense modalities. 
(ii) Where pairs of lexically parallel stems exist, their distribution over grammatically definable contexts is not clear-cut (Wiemer 2001), and there are hardly any grammatical forms which are restricted to one member of a pair, in contrast to East Slavic and Polish (Arkadiev 2011a; Arkadiev et al. 2015, 33).

However, I would like to argue that the major difference between Baltic and Russian is of a different kind: different lexical pairs make slightly different kinds of aspect-like distinctions. Put differently, Baltic 'aspect' works the way that Bermel claims for Old Russian. I will illustrate this with the difference between 'see' and 'smell' (for which Old Russian data is not available). The most suitable parallel text for 'smell' is P. Süskind's Das Parfüm. (The German original is indifferent to the relevant distinctions.) In this parallel text, the Baltic languages sometimes have specific 'smell' in the same kinds of contexts where there is unspecific 'see'; consider Lithuanian (38) for an example, testifying to the different behavior of 'see' and 'smell'.

(38) Lithuanian specific 'smell' and non-specific 'see' (P. Süskind, Das Parfüm)

[Kad jis visa to, žinoma,]

nematè neregèjo akimis, bet užuodè

NEG.See.PST.3 NEG.See.PST.3 eye.INS.PL but smell [SPEC].PST.3

[vis jautrëjančia ir stiprejjančia uosle.]

'[Of course,] he could not see any [of these things] with his eyes, but rather caught their scents [with a nose that from day to day smelled such things more keenly and precisely.]'

East Slavic languages, however, use aspect more consistently across sense modalities. The Russian and Ukrainian corresponding texts have only imperfective forms in this passage: Russian videl 'see[IPFV].PST.M.SG', čujal 'feel/smell[IPFv].PST.M.sG'. ${ }^{23}$

The difference between 'smell' and 'see' is even more manifest in Latvian than in Lithuanian. In Latvian specific 'see' is more seldom used than in Lithuanian, but specific 'smell' is more frequent:

${ }^{23}$ Ukrainian has bačyv 'see[IPFv].PST.M.sG' and vidčuvav 'feel[SPEC/IPFV].PST.M.sG'. Why the Ukrainian verb is specific is discussed below. 
(39) Latvian (P. Süskind, Das Parfüm)

[Kā vientula èrce, kas, sevì ievilkusies akla, kurla un mēma tup kokā un jūdžu attālumā]

gadiem ilgi saož klejojošu

year.DAT.PL long.ADV smell [SPEC].PRS.3 passing.ACC.SG

zvēru asinis,

animal.ACC.SG blood.ACC.PL.

'[The lonely tick, which, wrapped up in itself, huddles in its tree, blind, deaf, and dumb, and simply] sniffs, sniffs all year long, [for miles around,] for the blood of some passing animal'

Like the German original (wittert), the Baltic texts use opportunistic and not explorative verbs in this context whereas Russian and Ukrainian as English have explorative verbs. But the Lithuanian form is non-specific uodžia 'smell[NSPEC].PRs.3 and the Russian (vynjuxivaet 'sniff[IPFV].PRs.3') and Ukrainian (prynjuxuet'sja) forms are imperfective.

In (40), Latvian has specific 'smell' in coordination with non-specific 'see':

(40) Latvian: specific 'smell' in coordination with non-specific 'see' (P. Süskind, Das Parfüm)

tajā mirkli, kad viňš saoda

that.LOC.sG moment.ACC.SG when 3.NOM.SG.M smell [SPEC].PST.3

un redzeja,

and see [NSPEC].PST. 3

[cik efektivi tas darbojas, ]

'in that moment, as he saw and smelled [how irresistible its effect was]'

The corresponding Lithuanian text has two specific verbs: pamate ir užuode 'see[SPEC].PST.3 and smell[SPEC].PST.3'. The Ukrainian text has two imperfective forms: bačyv i vidčuvav 'see[IPFV].PST.M.sG and feel[SPEC/ IPFV].PST.M.SG'.

Ukrainian is extremely interesting in that it has prefixed secondary imperfective verbs. Ukrainian vidčuvaty 'feel, smell[SPEC/IPFV]' (derived from vidčuty 'feel, smell[SPEC/PFv]') is both specific and imperfective. The non-specific form is čuty 'hear, feel[NSPEC/IPFV]' (čuvaty would be iterative), which is used very rarely for 'smell'. In Ukrainian, the specific form has been almost fully generalized for 'smell', but at the same time 
aspect is not lexically specified in Ukrainian as in Russian and works the same for all perception verbs (or is at least much more consistent than in Baltic).

The different behavior of 'smell' may be related to the fact that smelling is a more explorative sense than 'see'. Smelling is an accompaniment of breathing as taste is of eating (Gibson 1966, 136). "Repeated sniffing probably maximizes the absorption of [...] vapor when its concentration is low" (Gibson 1966, 145). Thus, smelling is more of an accomplishment than seeing. On average, it takes more effort and especially more time to smell than to see. This makes smelling more specific than seeing. If specificity is not harmonized by a grammatical aspect system as in Russian throughout semantically heterogeneous verb pairs, the distinctions drift apart for different lexical domains. Hence, specific is not exactly the same thing for different perceptual systems in Baltic.

\subsection{Resolving the paradox: global aspect is underdetermined in perception verbs}

In Section 4 I have argued that specificity in Baltic can be interpreted in terms of restricted exposure. This is highly compatible with Dickey's global approach to Slavic aspect interpreting perfective aspect as totality or temporal definiteness. Restricted exposure is more temporally definite than unrestricted exposure. However, restrictedness of exposure is a scalar semantic distinction. If a language draws a categorical borderline between restricted and unrestricted exposure, it is not a priori clear where exactly this borderline is drawn. Different Slavic and Baltic languages draw this borderline in entirely different zones of the scale, as we have seen in Section 3. In languages where the non-specific verb prevails, such as Czech and Serbian-Croatian, Slavicists are inclined to claim that 'see' and 'hear' are anaspectual. However, the consideration of Baltic languages, with their primarily local character of the aspect distinction (different in different lexical domains), emphasizes the importance of the local approach which has only sporadically been investigated in Slavic languages, where it is mainly considered to be a diachronic transition from anaspectuality to regular global aspect. At the same time, specificity in Baltic languages lends itself to a classification in terms of global aspect where it clearly patterns with western rather than eastern Slavic languages (6.2.). 
This leads us to the conclusion that the global-local distinction is first of all a question of perspective. Specificity and aspect in Baltic and Slavic displays both local and global properties, albeit to different extents.

\section{Six potential clines in specific and obscured perception verbs across Eastern Baltic languages}

We are now in a position to summarize some elementary facts about specificity in Baltic perception verbs (or, more precisely, East Baltic, as there is virtually no evidence for Old Prussian ${ }^{24}$ ). There is much diversity across space and time in Baltic specific and obscured perception verbs. In this section I will argue that they can be effectively described in terms of six dimensions which limit the attested diversity. I will further explore to what extent the six dimensions can be considered clines. These are formulated in the form of hypotheses here:

Table 4. Hypotheses for six clines in Baltic specific and obscured perception verbs:

1. The morphological cline: From $n / s t$-verbs to simple prefixation and accomplishment verbs (see also Section 1)

2. The areal cline: Low Latvian $>$ Latgalian $>$ Lithuanian

3. The diachronic cline: The use of specific perception verbs increases across time

4. The specificity cline: A hierarchy of contexts with more or less restricted exposure (see also 3.4)

5. The modality cline: Different borderlines between specific and nonspecific for different sense modalities (see also 6.2)

6. The obscured verb cline: The likelihood that obscured verbs differ from specific perception verbs (see also Section 5)

\footnotetext{
${ }^{24}$ There is no evidence for specific perception verbs in Old Prussian (West Baltic), but no counter-evidence either. The form widdai 'see.PST.3', in a context where modern Lithuanian would have specific 'see' (Mažiulis 1981), is consistent with the hypothesis that Old Prussian is similar to Old Church Slavonic with anaspectual viděti which is what we probably have to reconstruct for Proto-Baltic and for Proto-Slavic anyway. But the very restricted evidence does not allow any conclusions.
} 
Dimensions 1-3 are particular Baltic dimensions, but partly have counterparts elsewhere in Central, East and Northern Europe. Dimension 4 , the specificity cline, applies to all languages of the specificity area. The modality dimension is particularly manifest in Baltic because of the lack of rigid aspect, and the major evidence for the obscured verb cline comes so far from Baltic languages.

7.1. The morphological dimension: from $n / s t$-verbs to simple prefixation and accomplishment verbs

As already mentioned in Section 1, Baltic languages have $n$ /st uncontrolled change-of-state verbs (non-causative/inchoative verbs with zero degree vocalism and an $n$-infix or st-suffix present stem; see Arkadiev 2013) in opposition to another morphological verb type for the nonspecific verb in the three major sense modalities 'see', 'hear' and 'feel': Lithuanian iš.vy.st.a 'see[SPEC].PRs.3', iš.gir.st.a 'hear[SPEC].PRs.3', and pa.ju<n $>$ t. a 'feel[sPEC].PRs.3'. As a tendency, this morphological opposition of verb stems tends to be blurred or fully abandoned in modern varieties of Lithuanian and Latvian where it is either replaced by simple prefixation with identical bases for (non-)specific verbs or where the specific verb is formally an accomplishment explorative verb:

Figure 7. The morphological cline:

$n /$ st-uncontrolled change of state (---- > irregular stem forms) --- > loss of base alternation prefixation $>$ simple prefixation, or, accomplishment explorative verb

In 16th and 17th century Lithuanian, specific 'see' is ǐ̌.vys.ti, PRs iš. vy. st.a (st-inchoative present stem), PST iš.vyd.o and non-specific 'see' is regetti with $i / \dot{e}$-stems characteristic of stative verbs:

(41) Lithuanian: Bretkūnas (1579-80; Exodus 14.13; Bretkūnas 1983) Nesaschus Egypcianis, kurius sche diena for this.ACC.PL E.ACC.PL which.ACC.PL this.ACC.sG day.ACC.sG regite, ius niekadai nebeischwisit see [NSPEC].PRS.2PL 2PL.NOM never NEG.CNT.See [SPEC] 


\section{amszinai}

eternal.ADV

'for the Egyptians whom ye have seen to day, ye shall see them again no more for ever.'

While išvysti and regeti still exist in modern Lithuanian (the latter mostly restricted to 'see' as ability), the dominant forms are now pamatyti 'see[SPEc]' and matyti 'see[NSPEC]', which seem to represent a recent innovation, although they can be observed in most Lithuanian dialects (including Žemaitian dialects, e.g., Bacevičiūtè et al. 2004, 265, 267). In the Chyliński Bible (1659) there is only one occurrence of matyti in the Gospel according to Mark. Whatever the etymological source of matyti and pamatyti (see 7.6), these verbs relexicalize the distinction that was already established by regeti and išvysti in Old Lithuanian.

In Latvian there is no trace of a correspondence to -vysti. Instead, an accomplishment explorative verb ie-raudzit 'in-look' is used already in the Glück Bible 1689. The accomplishment origin is still alive in such uses as ...meklē Kārli. Pēdīgi vina to ierauga 'looks for Karlis. Finally she sees him' (Brāḷi Kaudzītes, Mērnieku laiki 3,5) or gājis raudzīt un-ieraudzījis Grabovski 'went to see and saw Grabovski' (Brāl,i Kaudzītes, Mērnieku laiki $3,5)$, see also examples (4) and (10) above. Elgers has ieredzèt (1x) in the same function, Bet tas Kanings egaia lûkot tös we es, un ercedzœia tur venu cilwaku 'But when the king came in to see the dinner guests, he saw a man' (Matth. 8.22; Draviňš 1961, 111). Considered in isolation ercedzœia see[SPEC].PST. 3 has an achievement meaning here, but it occurs in an ambulatory vision context following egaia lûkot [in.go.PST.3 look.INF] where it can also be interpreted as an accomplishment. ${ }^{25}$

For 'hear' modern Lithuanian maintains the st-inchoative (present iš.gir.st.a). Latvian, however, vacillates between izdzirst and izdzirdèt, the latter in analogy to the stem of non-specific dzirdēt 'hear'. In the past iz.dzird.a (morphologically the past of iz.dzirs.t) is preferred in more conservative Latvian varieties and in Latgalian. In the present, however, $i z . d z i r d$ (morphologically the present of iz.dzird.ēt) and in the infinitive iz.dzird.èt are preferred often also in texts that have the past iz.dzird.a. This suggests that many Latvian speakers might have only one lexeme

${ }^{25}$ ieraudzit occurs six times in ambulatory vision contexts and for seeing from a large distance (Draviņš \& Ozola 1976, 53). In modern Latvian, ieredzēt cannot be used as specific 'see', but rather means 'to respect'. 
izdzirdèt with alternative forms for the past (izdzirda and izdzirdēja); the same holds for padzirdèt 'hear (superficially), where the past participle padzirdis can occur instead of padzirdējis as in (9).

Lithuanian justi (present with $n$-infix junta) and jausti (present jaučia), exhibiting base alternation, both mean 'feel', but show considerable differences in usage, as shown by Arkadiev $(2013,56)$. The dominant unprefixed form is jausti (more than 20 times more common in the present and about 5 times more common in the past), whereas prefixes attach almost exclusively to justi. In Latvian there is no base alternation left, the prefixed specific sajust and the unprefixed non-specific verb just have the same stems which continue the $n$-inchoative: present $(s a$-)jūt $<* j u n t a$.

We may conclude that specific verbs are originally very tightly connected to the morphological class of $n$ /st-uncontrolled change-of-state verbs. However, there is not the slightest evidence that 'smell' would ever have been involved. ${ }^{26}$ The connection to $n / s t$ verbs becomes gradually weaker and specificity is increasingly associated with simple prefixation.

\subsection{The areal dimension: Low Latvian $>$ Latgalian $>$} Lithuanian

In standard Latvian the most common use of ieraudzit is with a direct object; it is rarely used with a sentential complement or without object or complement. In order to give just one example from a random text, of 24 occurrences in A. Niedra's novel Liduma dūmos, 21 are with a direct object. Two of the remaining three other ones are obscured uses with poor illumination conditions. There are no occurrences of ieraudzit in the future tense and the most typical grammatical categories attested are past, past participles and converbs.

The more extended use of specific 'see' in Latgalian has already been illustrated in (2) from a short story by J. Pūrmalìts. In Low Latvian ieraudzit is hardly ever used without object and in historical present as in (2). The Latgalian NT has a higher rate of occurrence of ieraudzit than any other Latvian Bible translation (22 times in Mark). However, the difference between Low Latvian and Latgalian is most manifest for specific 'hear' (see Table 5 below). The clearest difference between Lithuanian

\footnotetext{
${ }^{26}$ According to Stang $(1942,119)$ the present stem Lithuanian uodžia 'smells' might derive from an athematic present with ablaut.
} 
and Latvian/Latgalian specific 'see' is the frequently attested future use in Lithuanian, and this holds already for the earliest Bible translation by Bretkūnas (see (41) above). The common saying Latvian kad dzivosim, tad redzēsim [when live.FuT.1PL then see[NSPEC].FuT.1PL] with non-specific 'see' translates in Lithuanian to pagyvensim-pamatysim [live.FUT.1 PL see[SPEC].FUT.1PL] (LLKž 553) with specific 'see'. ${ }^{27}$

These facts taken together are evidence for an areal cline: Low Latvian $>$ Latgalian $>$ Lithuanian.

7.3. The diachronic dimension: The use of specific perception verbs increases across time

While the areal cline is very obvious, there is more limited evidence for a diachronic cline both in Lithuanian and in Latvian. While the Chyliński Bible (1659) has a similar ratio of specific 'see' and 'hear' as modern Lithuanian Bible translations (with the difference that Chyliński has išvysti instead of pamatyti, see 7.1), the Bretkūnas Bible (1579-80) clearly has a more restricted use of specific 'see' and 'hear'.

(42) Lithuanian (Exodus 3.4)

Bretkūnas:

A kaip Ponas regeia, ghị

and how lord.NOM.sG see [NSPEC].PST.3 3. ACC.SG.M

beenti weisdetu...

CNT.go.PRS.PA.ACC.SG look.sUP

1998

Kai Viešpats pamate, kad Moze

when lord.NOM.SG see [SPEC].PST.3 that Moses.NOM

pasuko pasižiūrèti

return.PST.3 PVB.RFL.see.INF

'And when the Lord saw that Moses turned aside to see, [God called unto him out of the midst of the bush]'

Across Latvian Bible translations there is a clearly notable historical cline in the use of ieraudzit 'see[SPEc]' both qualitatively and quantitatively. In the Glück Bible (1689) ieraudzit only occurs twice in Mark and both

${ }^{27}$ A lexicalized particular meaning of the Lithuanian specific reflexive pasimatyti is 'see again'. 
times in passages where it can be interpreted as accomplishment 'look' where it is preceded by an explorative 'look' verb. In the UBS version of 1965 , which is generally quite conservative, there are four occurrences of ieraudzit 'see[SPEC]' in Mark, two of which are used in 'see from far' contexts. In the 2012 version ieraudzit occurs 19 times and has almost the same distribution as in the Latgalian translation (see Table 5).

Both Latvian traditional fairy tales and the dainas (Latvian traditional folk songs) have a high occurrence of specific 'see' and 'hear', which might be taken as evidence against a diachronic cline in Latvian given the archaic language of the dainas. However, the dainas are also characterized by desemantization. Often there is not enough context to decide whether or not there is exposure in perception. Hence, it cannot be excluded that dainas have register-specific features favoring the occurrence of specific verbs. Dainas very often play with the non-occurrence or occurrence of expected or unexpected events, which are often framed in form of perception. Example (43) also suggests that polarity might be a factor.

(43) Play with non-specific and specific 'hear' in the dainas (Dainas 22905-1)

Nedzirdēju māsas vārdu. /

NEG.hear [NSPEC].PST.1sG sister.GEN.SG name.ACC.SG

$\mathrm{Nu}$ izdzirdu māsas vārdu

now hear [SPEC].PST/PRs.1sG sister.GEN.SG name.ACC.SG

'I did not hear the sister's name / Now I hear the sister's name.'

(44) Specific 'see' in present tense in the dainas (Dainas 10134-0)

Labak vilku es ieraugu, /

better wolf.ACC.SG I.NOM see [SPEC].PRS.1sG

$\mathrm{Ne}$ dzèraja tēva dèlu;

NEG drunkard.GEN.sG father.GEN.SG son.ACC.SG

'Rather I want to see the wolf / than the son of a drunkard's father [/ To the wolf I scream, the wolf runs away / What can I do to the drunkard?]'

Since the Latvian specific verb ieraudzit 'see[SPEC]' is an innovation and has developed in ambulative and obscured contexts where it can be interpreted as an accomplishment, since ieraudzit in specific use is increasing in Latvian texts across time, and since there is no trace of an etymological equivalent to Lithuanian išrysti, there is evidence for a diachronic cline at least in Latvian. 
The question as to whether Lithuanian specific 'see' and Baltic specific 'hear' increase across time needs further investigation. In an areal context, specific verbs are increasing in Eastern Europe and the CircumBaltic area. Old Church Slavonic and Old Russian do not have a specific/ perfective verb as Russian uvidet'. There are no specific perception verbs of the kind Hungarian has in any other Uralic language. Prefixation characteristic for specific verbs in Georgian was not developed to the same extent in Old Georgian. The oldest Swedish Bible translation has much fewer occurrences of $f a ̊ s e$ 'see[SPEC]' than the newer ones.

7.4. The specificity scale: a hierarchy of contexts with more or less restricted exposure

The specificity cline has been introduced in Section 3 where it emerged as the result of an MDs-analysis of a cross-linguistic dataset. The details of the cline need still to be worked out, but certain contexts can be clearly located on the scale. The most specific contexts comprise seeing from a distance and seeing while approaching. If we restrict the cline to opportunistic perception, the most non-specific contexts are present tense notably with a speech act participant as subject. However, the most nonspecific contexts cannot be easily defined as the scale further extends to ability, ambulatory perception and explorative perception to the right (see 3.3).

Figure 8. The specificity cline, a first approximation

$\begin{array}{llll}\begin{array}{l}\text { distance } \\ \text { while }\end{array} & \begin{array}{l}\text { restricted } \\ \text { exposure }\end{array} & \begin{array}{l}\text { exposure } \\ \text { synchronized } \\ \text { with percep- }\end{array} & \text { experiential present tense } \\ \text { approach- } & & \text { perfect }> & \text { with speech } \\ \text { ing }> & \text { tion }> & \text { act partici- }\end{array}$

$<$ most specific contexts most non-specific contexts $>$

Inceptive states do not figure on the proposed cline. Inceptive examples are understood here as a special case of exposure synchronized with perception. The more factive and the more predetermined the transition to perception, the more specific the context. This is why future (nonfactive and usually not fully predetermined) is further to the right in a 
segment of the scale where Latvian and Lithuanian differ (see 7.2). The predilection of Latvian ieraudzit 'see[SPEC]' for direct objects may be an idiosyncrasy, but the explicitly mentioned object also restricts the verb and makes perception more specific.

Figure 8 neglects the factor of polarity, which probably plays an important role. There are many examples where negation goes together with non-specific verbs, e.g., (43).

It has to be emphasized that the scale suffers from a strong bias toward vision, as it is modelled exclusively on the basis of visual perception. One cannot therefore take for granted that it is equally applicable to other perceptual systems.

\subsection{The modality dimension: Different borderlines between} specific and non-specific for different sense modalities

In Lithuanian and even more markedly in Latvian the borderline between specific and non-specific is not the same for different perceptual systems. In 6.2 we have seen that 'smell' is more inclined to be specific than 'see' in Latvian and (to a lesser extent) Lithuanian. Modern Latvian differs from Latgalian and Lithuanian in that specific 'hear' is more restricted than specific 'see'. This is, for instance, very manifest in the Latvian 2012 Bible translation (see Table 5):

Table 5. Number of specific verbs in the Gospel according to Mark

\begin{tabular}{l|r|r|r|r}
\hline & Latvian & Latvian & Latvian & Latgalian \\
& 1689 & 1965 & 2012 & 1933 \\
\hline 'see[SPEC]' & 2 & 4 & 19 & 22 \\
'hear[SPEC]' & 0 & 4 & 4 & 13 \\
'see[NSPEC]' & 62 & 58 & 48 & 27 * \\
'hear[NSPEC]' & 36 & 29 & 29 & 14
\end{tabular}

*The lower number here is mainly due to the fact that the attention-catching imperative context (behold! lo! Latin ecce!) is not expressed by redzēt 'see[NSPEC]' in the Latgalian translation. 
On the other pole of the cline there is specific 'feel' which behaves in a similar way to specific 'smell' (it has the same prefix sa-and is partly expressed by the same verb sajust). This yields the following modality cline in Latvian:

Figure 9. Modality cline in Latvian for the borderline between specific and non-specific verbs

'hear' 'see' 'feel', 'smell'

Non-specific more extended $<$ $>$ Specific more extended

To pick the same random text as above, in A. Niedra's novel Liduma dūmos, for instance, izdzirst/izdzirdèt 'hear[SPEC]' occurs 2 times (1.6\%; dzirdēt 'hear[NSPEC]' 122 times), ierauzdit 'see[SPEC]' 24 times (6.3\%; redzèt 'see[NSPEC]' 358 times), but sajust 'feel[SPEC]' 40 times (25.3\%; just 'feel[NSPEC]' 118 times). ${ }^{28}$ Sajust 'feel[SPEC]' is attested both in future tense and in experiential perfect use, which is not the case for ierauzdit 'see[SPEC]':

(45) Specific 'feel' in future tense (A. Niedra, Lìduma dūmos)
bet tomēr
viňš
nekad nesajutis

but nevertheless 3.sG.NOM.M never NEG.feel[SPEC].FUT.3

tā nemiera

that.GEN.SG NEG.peace.GEN.SG

'but still he will never feel that uneasiness'

(46) Specific 'feel' in experiential perfect (A. Niedra, Lìduma dūmos)

Jeb vinas vēl laimes nekad nav

or 3.PL.NOM.F still luck.GEN.SG never NEG.be.PRS.3

sajutušas.

feel [SPEc].PST.PA.NOM.F.PL.

'Or they have never felt luck'

There is thus clear evidence that specificity does not behave the same in Latvian across sense modalities. In Lithuanian there is evidence for deviant behavior of 'smell' (see Section 6).

${ }^{28}$ The numbers rely on counts based on automatic text recognition; some few tokens may have been missed. Niedra's text seems to be representative for Latvian in general except for the high occurrence of 'feel' (it is a quite sentimental novel). 
7.6. An obscured verb cline? The likelihood that obscured verbs differ from specific perception verbs

As we have seen in Section 5, the Baltic languages differ according to which perceptual systems have different specific and obscured verbs. In literary Latvian 'see' and 'hear' have different verbs, 'feel' partly the same, and 'smell' the same verbs. In literary Lithuanian, only 'see' has a distinct obscured verb. This yields the following cline, which happens to look like Viberg's lexicalization and markedness hierarchy:

Figure 10. Obscured verb cline:

'see' > 'hear' (> 'feel') > 'smell'

Not only in Lithuanian, but also in Latvian, the scale is due most markedly to a dominance of vision. Vision is not only inclined to have one special obscured verb; in certain dialects of Latvian there are several dedicated obscured perception verbs. Let us consider the dialect of Ërgeme in North-Western Vidzeme at the Estonian border, which happens to boast a particularly profound lexical documentation (Kagaine \& Rage 1977-1983 $=$ EIV).

Ergeme Latvian does not only have obscured verbs with prefixes, but even two non-prefixed ones. One of them, viêdêt, is specialized for poor illumination: viẽdêt 'to see with difficulties (in poor illumination)' and it can also mean 'to dawn'.

(47) Latvian, Ērǵeme dialect: non-prefixed obscured 'see' verb (ĒIV iii, 711)

viņč $i$ tik traku tùmš,

3.NOM.SG.M be.PRs.3 so_much terribly dark.NOM.sG.M

drusku jàu tik vàr viêdêt tùo

a_bit already only can.PRs. 3 see[oBsc].INF that.ACC.sG

celu

way.ACc.sG

'it is so terribly dark, already one can see the road only a bit.'

Other typical uses of obscured verbs, such as 'see from great distance' and 'old person with impoverished sight', are attested for viedèt in other Latvian dialects (ME iv, 652). The verb is cognate with Lithuanian 
veizdeti 'look, watch'-most common in Old Lithuanian (see example (42) Bretkūnas), išvysti 'see[sPEc]', and Slavic viděti 'see'. Another obscured perception verb in Ërgeme used only by older speakers when documented in the second half of the 20th century is matit (nemaz matît nevarẽja [absolutely see[oвsc] NEG.can.PST.3] 'could not at all be seen') which is etymologically identical with Lithuanian matyti 'see[NSPEC]'. In other varieties of Latvian matit sometimes has the meaning 'feel, realize'; the reflexive matities is 'seem'. ${ }^{29}$ The further cognates of this word are the Lithuanian adjective (ǐ̌-)matrus 'careful', ìmatrus 'skillful' and Russian smotret' 'watch, look' (in dialects also motret' with $s$ - being a prefix diachronically, see Vasmer 1976-1980) and perhaps mest 'throw' (Fraenkel 1962-1965).

A further interesting verb in Ërgeme is uzskatît 'see[SPEC/oBsc]; look after' (ĒIv iii, 636) which has both specific (gàisã usskata kâdu putnu '[the dog] sees a bird in the air, [and runs and barks]') and obscured use (grãvmalẽ uôgas nevàr usskatît tũlitẽm 'at the border of the ditch one cannot see the berries immediately'). In specific use it is a synonym of ieraũdzît. The specific and obscured meanings are not present in literary Latvian and most other varieties of Latvian. In literary Latvian uzskatit is 'consider to be' and 'look after' and in Glück's Bible translation it can have the meaning 'look up', which is probably its original meaning: skatit 'glance, look', uz- 'up'.

The Ėrgeme examples viêdêt, matit and uzskatit show that that there is a recurrent drift to develop obscured verbs for visual perception in varieties of Baltic. The fact that Lithuanian has a st-uncontrolled change-ofstate verb išgirsti for both obscured and specific 'hear' suggests that 'hear' is more conservative and less productive in this respect. This does not explain the difference between 'hear' and 'smell, feel' in Latvian, which may be due to sheer coincidence, as $s a$ - just happens to be the productive prefix for obscured verb formation and the prefix of specific 'feel' and 'smell' verbs.

\section{Conclusions}

Lexical distinctions made in 'see' and 'hear' in Lithuanian and Latvian are very similar to aspect distinctions in 'see' and 'hear' in Russian

\footnotetext{
${ }^{29}$ I do not think mast in the fixed phrase ne just, ne mast [not feel.INF not ?.INF] (ME ii, 565) is
} a complete verb. It is rather an analogical adaptation of matit 'feel' to the form of just 'feel'. 
and other Slavic languages. This paper introduces the cover terms 'nonspecific and specific perception verbs' for both lexical and grammatical distinctions (Section 1) and argues that specificity is semantic, that it is not a dichotomy, but rather a scale, and that it is determined by conditions-notably restrictedness of exposure-rather than participant structure. These conclusions are at odds with several basic assumptions in the literature on lexical aspect and perception verbs, but consistent with psychological approaches to perception, such as James J. Gibson's ecological psychology and Irvin Rock's indirect perception. Nine biases in traditional approaches to perception verbs are identified (Section 2). This paper addresses in particular the discrete-feature bias, which-due to categorization in particular languages-can be overcome only by cross-linguistic comparison on the level of language use, and the participant-orientation bias, which obstructs the view for the relevance of conditions in aspectual structure. Since it is nearly impossible to address all biases at a time, triangulation is required. Several methods, such as probabilistic semantic maps built with multidimensional scaling from parallel text data (Section 3) and the study of conditions in selected example from original texts (Section 4), must be combined in order to overcome the biases. Obscured perception verbs, which emphasize difficulty in discrimination, are identified as a further group of perception verbs in Baltic and Russian which focus on conditions of perception (Section 5). It is found that obscured and specific perception verbs are closely related synchronically and diachronically. The paradox that 'see' and 'hear' are among the verb domains with most strongly aspectual behavior in Lithuanian and Latvian while 'see' and 'hear' are at the same time among the most irregularly behaving verb domains in Slavic aspect is resolved by arguing that the global aspect distinction in Slavic is underdetermined in perception verbs (Section 6). Restrictedness of exposure is consistent with perfective aspect, but, since restrictedness of exposure is a scale rather than a dichotomy, there are many different possible borderlines in language-particular categorization, which accounts for the attested diversity in Slavic and Baltic. The considerable variability in non-specific, specific, and obscured perception verbs in Baltic languages is captured in terms of six dimensions, three of which (morphology, area, diachrony) are of crucial interest for Baltic studies and, in a wider perspective, for languages of Central, East and Northern Europe, whereas 
the other three (specificity, modality, obscured verbs) have the potential to be of more universal relevance (Section 7). However, further research has to show how idiosyncratic specificity, which is an areal feature of Central, East and Northern Europe, is in a global perspective and how it relates, for instance, to 'see from a distance' verbs, such as attested in Tagalog and Mandinka.

\section{Bernhard Wälchli}

Stockholms universitet

Institutionen för lingvistik

SE-10691 Stockholm

bernhard@ling.su.se

\section{Acknowledgements}

I am very grateful to Johanna Nichols whose talk at the Workshop "Resulting states" at Stockholm University on November 22, 2015 inspired me to start looking at the typology of perception verbs. This paper has greatly profited from many useful comments by Peter Arkadiev, Wayles Brown, Östen Dahl, Axel Holvoet, Johanna Nichols, Robert Wälchli, Ruprecht von Waldenfels, Björn Wiemer and two anonymous reviewers. I am grateful to Anna Zaliznyak and Lilita Zalkalns for important literature. While writing this paper I was funded by the Swedish Research Council (Vetenskapsrådet, 421-2011-1444).

\section{AbBReviations IN GLOSSES}

ACC - accusative, ACN - action noun, ADV - adverb, CNT continuative, COMP - comparative, CONEG - connegative form, CVB - converb, DAT - dative, DEF - definite, DELIM - delimitative, DIM - diminutive, F - feminine, FUT — future, GEN — genitive, HAB habitual, HORT - hortative, IDEF - indefinite, IMP - imperative, INF infinitive, INS - instrumental, IPFV — imperfective, IRR - irrealis, ITER - iterative, LOC - locative, M - masculine, NOM - nominative, NEG - negative, NSPEC - non-specific perception, OBSC - obscured perception, PA - active participle, $\mathrm{PFV}$ - perfective, $\mathrm{PL}$ - plural, $\mathrm{PP}-$ passive participle, PRS - present, PST — past, PTC — particle, PVB - 
preverb, RFL - reflexive, RSTR - restrictive, SG - singular, SPEC specific perception, suP - supine, voc — vocative

\section{SOURCES}

Aputis, J.: Dvi apysakos: Prieš lapų kritima / Skruzdèlynas Prūsijoje. 1996. Vilnius: Baltos lankos.

Blaumanis, R.: www.korpuss.lv/klasika/Senie/

Bretkūnas Bible: Range \& Scholz (1991), Bretkūnas (1983).

Bulgakov, M.: www.parasolcorpus.org

Chyliński Bible: Kudzinowski \& Otrębski (1958)

Dainas: http://www.dainuskapis.lv

Deglavs, A.: www.korpuss.lv/klasika/Senie/

Glück Bỉble 1689: Bībele: Vecās un Jaunās derïbas Svētie raksti: pirmās latviešu bibeles. Minneapolis: Latviešu evangeliski-luterisko draudžu apvienība, 1974.

Kaijaks, V.: Rēgi, 1993. Karogs: Rīga.

Brāḷi Kaudzītes, Mērnieku laiki www.korpuss.lv/klasika/Senie/

Kazakov, J.: Arktur, der Jagdhund. Russisch / Deutsch. 1976. Stuttgart. Reclam.

Niedra, A: Lìduma dūmos. 1992. Rīga: Zinātne.

Pūrmalīts, J.: Kursìte \& Stafecka (2003, 221-228)

Süskind, P.: www.parasolcorpus.org

\section{REFERENCES}

Arkadiev, Peter. 2011a. On the aspectual uses of the prefix be- in Lithuanian. Baltic Linguistics 2, 37-78.

Arkadiev, Peter. 2011b. Aspect and actionality in Lithuanian on a typological background. In: Daniel Petit, Claire Le Feuvre \& Henri Menantaud, eds., Langues baltiques, langues slaves. Paris: Éditions CNRs, 57-86.

Arkadiev, Peter. 2013. From transitivity to aspect: the causative-inchoative alternation and its extensions in Lithuanian. Baltic Linguistics 4, 39-77.

Arkadiev, Peter. 2014. Towards an areal typology of prefixal perfectivization. Scando-Slavica 60.2, 384-405. 
ArKadiev, Peter. 2015. Areal'naja tipologija prefiksal'nogo perfektiva (na materiale jazykov Evropy i Kavkaza). Moskva: Jazyki slavjanskoj kul'tury.

Arkadiev, Peter, Axel Holvoet \& Björn Wiemer. 2015. Introduction: Baltic linguistics-State of the art. In: Peter Arkadiev, Axel Holvoet \& Björn Wiemer, eds., Contemporary Approaches to Baltic Linguistics. Berlin: De Gruyter, 1-109.

Bacevičiūtė, Rima, Audra Ivanauskienė, Asta Leskauskaitė \& EdMundas TRUMPA. 2004. Lietuvių kalbos tarmių chrestomatija. Vilnius: Lietuvių kalbos instituto leidykla.

Beaulieux, LÉon. 1950. Grammaire de la langue bulgare. 2e édition. Paris: Institut d'études slaves.

Bermel, NeIL. 1997. Context and the Lexicon in the Development of Russian Aspect. Berkeley: University of California Press.

Breu, WALter. 1980. Semantische Untersuchungen zum Verbalaspekt im Russischen. München: Sagner.

Breu, WALter. 1998. Komplexe aktionale Verbklassen, insbesondere Inchoativa. In: Tilman Berger \& Jochen Raecke, eds., Slavistische Linguistik 1997. Referate des xxıII. Konstanzer Slavistischen Arbeitstreffens Blaubeuren, 26.-28.8.1997. München: Sagner, 55-80.

BRETKūNAs, JonAs. 1983. Rinktiniai raštai. Vilnius: Mokslas.

Bunčić, DANIEL. 2013. Biaspektuelle Verben als Polyseme: Über Homonymie, Aspektneutralität und die konative Lesart. Die Welt der Slaven 58: 36-53.

Croft, William. 2012. Verbs. Aspect and Causal Structure. Oxford: Oxford University Press.

DAHL, Östen. 1985. Tense and Aspect Systems. Oxford: Blackwell.

Daugavet, AnNA. 2015. Latvian dabūt 'get': An acquisitive modal? Baltic Linguistics 6, 9-44.

Dickey, Stephen M. 2000. Parameters of Slavic Aspect. A cognitive approach. Stanford, CACSLI Publications.

DivjAK, DAgmar. 2015. Exploring the grammar of perception. A case study using data from Russian. Functions of Language 22.1, 44-68.

Dowty, DAvid R. 1979. Word Meaning and Montague Grammar. Dordrecht: Reidel.

DrAviN̦š, KĀRLIS. 1961. Evangelien und Episteln ins Lettische übersetzt von Georg Elger. Bd 1. Texte. Lund: Slaviska institutionen vid Lunds Universitet. 
Dravin̦š, KĀRlis \& Mirdza Ozola, eds. 1976. Evangelien und Episteln ins Lettische übersetzt von Georg Elger. Bd 2. Wortregister. Lund: Slaviska institutionen vid Lunds Universitet.

ĒIV = KAGAINE \& RAĢE 1977-1983.

Engen, Trygg. 1982. The Perception of Odors. New York: Academic Press. Evans, Nicholas \& David Wilkins. 2000. In the mind's ear: The semantic extensions of perception verbs in Australian languages. Language 76.3, 546-592.

Faber, Pamela \& Chantal Pérez. 1997. Image schemata and light: A study in contrastive lexical domains in English and Spanish. Acta Universitatis Lodziensis. Folia Linguistica 36, 63-107.

Fedden, Olcher Sebastian. 2007. A grammar of Mian, a Papuan language. Diss., University of Melbourne.

FRAENKEL, ERNST. 1962-1965. Litauisches Etymologisches Wörterbuch. 2 Bde. Idg. Bibliothek, Wörterbücher. Heidelberg: Winter.

Galton, Antony. 1984. The Logic of Aspect. Oxford: Clarendon Press. Galton, Herbert. 1976. The Main Functions of the Slavic Verbal Aspect. Skopje: Macedonian Academy of Sciences and Arts.

Gibson, James J. 1966. The Senses Considered as Perceptual Systems. London: Allen.

Gibson, James J. 1979. The Ecological Approach to Visual Perception. Reprinted 2015 New York: Psychology Press.

GRøNn, AtLE. 2003. The semantics and pragmatics of the Russian factual imperfective. Ph.D. thesis. Oslo: University of Oslo.

Gruber, JEFFrey S. 1967. Look and see. Language 43.4, 937-947.

Haiman, John. 1985. Natural Syntax. Cambridge: Cambridge University Press.

HeRz, RACHEL. 2007. The Scent of Desire. Discovering our enigmatic sense of smell. New York: Morrow.

Holvoet, Axel. 1993. Towards a typology of aspect systems in Slavonic. Slavica Gandensia 20, 25-32.

Horie, KaORU. 1993. A cross-linguistic study of perception and cognition verb complements: a cognitive perspective, Diss., University of Southern California.

Huber, BrigitTE. 2005. The Tibetan Dialect of Lende (Kyirong): a grammatical description with historical annotations. Bonn: VGH Wissenschaftsverlag $\mathrm{GmbH}$. 
IbarretXe-Antuñano, Iraide B. 1999. Polysemy and metaphor in perception verbs: a cross-linguistic study, Diss., University of Edinburgh.

Inoue, KazuKo. 1975. Studies in the perfect. Unpublished dissertation, Univ. of Michigan.

Jakobson, Roman. 1957/1971. Shifters, verbal categories, and the Russian verb. In: R. Jakobson, Selected Writings II: 130-147. The Hague: Mouton.

Kagaine, E. \& SilviJa RaĢE. 1977-1983. Ērǵemes Izloksnes Vārdnīca IIII. Rīga.

Kudzinowski, CzesŁaW \& JAN OtręBSKI, eds. 1958. Biblia litewska Chylińskiego: Nowy Testament. T. 2, Tekst. Poznań: Ossolineum.

Kurs̄̄te, JAN̄̄nA \& ANNA StAFEcKA. 2003. Latgale: Valoda, literatūra, folklora. Rēzekne: Latgales kūltūras centra izdevniecība.

LAKoff, George \& Mark Johnson. 1980. Metaphors We Live By. Chicago: The University of Chicago Press.

LEHMANN, VolKer. 1989. Besonderheiten der Verwendung von videt' ,sehen' / slyšat' ,hören' im Russischen und die Konservierung älterer Sprachzustände. In: Wolfgang Girke, ed., Slavistische Linguistik 1988. Referate des XIV. Konstanzer Slavistischen Arbeitstreffens Mainz, 27.-30.9.1988. München: Sagner, 139-146.

LeInONen, MarJA. 1982. Russian Aspect, "temporal'naja lokalizacija” and Definiteness/Indefiniteness. Helsinki: Neuvostoliitto-instituutin vuosikirja.

LLKž = JoNAS BALKEVIČIUS \& JoNAS KABELKA. 1977. Latvių-lietuvių kalbų žodynas. Vilnius: Mokslas.

LöBneR, SEbastian. 1988. Ansätze zu einer integralen semantischen Theorie von Tempus, Aspekt und Aktionsarten. In: Veronika Ehrich \& Heinz Vater, eds., Temporalsemantik. Tübingen: Niemeyer, 163-191. LOCKE, JoHN. 1975 [1690-1714]. An essay concerning human understanding. Edited by Peter H. Nidditch. Oxford: Clarendon.

Lunt, Horace G. 1952. Grammar of the Macedonian Literary Language. Skopje: Državno knigoizdatelstvo na NR Makedonija.

MACK, ArIEN \& IRvin Rock. 1998. Inattentional Blindness. Cambridge, Mass.: The MIT Press.

MasLov, Ju. S. 1948. Vid i leksičeskoe značenie glagola v sovremennom russkom literaturnom jazyke. Izvestija Akademii nauk sssR: Otdelenie literatury i jazyka 7.4, 303-316. Reprinted in Maslov (1984). 
Maslov, Ju. S. 1984. Očerki po aspektologii. Leningrad: Izdatel'stvo Leningradskogo universiteta.

Mažıulis, Vytautas, ed. 1981. Prūsų kalbos paminklai. T. 2. Vilnius: Mokslas.

ME = KĀRLIS MǖLENBACHS \& JĀNIS ENDZEL̄̄NS 1923-1932. Karlis Mühlenbachs Lettisch-Deutsches Wörterbuch. Ergänzt und fortgesetzt von Janis Endzelin. 1-4. Rìga.

NAKAgawa, Hiroshi. 2012. The importance of taste verbs in some Khoe languages. Linguistics 50.3, 395-420.

Nesset, ToRe. 2010. Is the choice of prefix arbitrary? Aspectual prefixation and Russian verbs of perception. The Slavic and East European Journal 54.4, 666-689.

Paducheva, Elena V. 2004. Dinamičeskie modeli v semantike leksiki. Moskva: Jazyki slavjanskoj kul'tury.

Piperski, Alexander. n.d. Between imperfective and perfective: quantitative approaches to the study of biaspectual verbs. https://www. academia.edu/21426579/Between_imperfective_and_perfective_ quantitative_approaches_to_the_study_of_Russian_biaspectual_verbs

RANGe, Jochen Dieter \& Friedrich Scholz, eds., 1991. Navias testamentas, ing lietuwischkạ lieszuwị perraschitas per Janạ Bretkuna = Das Neue Testament, in die litauische Sprache übersetzt von Johann Bretke. Biblia Slavica. Serie 6, Supplementum: Biblia Lithuanica. Paderborn: Schöningh.

Rock, Irwin. 1983. The Logic of Perception. Cambridge, Mass.: The MIT Press.

Rock, IRwin. 1997. Indirect Perception. Cambridge, Mass.: The MIT Press. Rogers, ANDy. 1971. Three kinds of physical perception verbs. Chicago Linguistic Society 7, 206-222.

Rogers, ANDy. 1972. Another look at flip-perception verbs. Chicago Linguistic Society 8, 303-315.

Ryle, Gilbert. 1949. The Concept of Mind. London: Barnes.

Schuyt, Roel. 1990. The Morphology of Slavic Verbal Aspect. A Descriptive and Historical Study. Amsterdam: Rodopi.

Scovel, Thomas S. 1971. A look-see at some verbs of perception. Language Learning 21, 75-84.

Stang, Christian S. 1942. Das slavische und baltische Verbum. Oslo: Dybwad. 
SweEtSer, Eve. 1990. From Etymology to Pragmatics. Metaphorical and cultural aspects of semantic structure. Cambridge: Cambridge University Press.

TAtevosov, Serges. 2002. The parameter of actionality. Linguistic Typology 6, 317-401.

Van Valin, Robert. 2001. An Introduction to Syntax. Cambridge: Cambridge University Press.

VASMER, MAx. 1976-1980. Russisches etymologisches Wörterbuch. I-III. 2., unveränderte Auflage. Heidelberg: Winter.

Vendler, Zeno. 1967. Linguistics in Philosophy. Ithaca, New York: Cornell University Press.

Veselinova, LuUba. 2006. Suppletion in Verb Paradigms. Amsterdam: Benjamins.

Viberg, Åke. 1983. En typologisk undersökning av perceptionsverben som ett semantiskt fält. In: Åke Viberg, ed., Studier i kontrastiv lexikologi: perceptionsverb, 2, 21-96. SSM Report 8. Stockholm: Stockholms Universitet.

VIBERG, ÅKe. 1984. The verbs of perception: a typological study. Linguistics 21.1, 123-162.

VIBERG, ÅKe. 2001. Verbs of perception. In: Martin Haspelmath, Ekkehard König, Wulf Oesterreicher \& Wolfgang Raible, eds., Language Typology and Language Universals: An International Handbook. Berlin: Walter de Gruyter, 1294-1309.

WÄLChli, BernhaRd \& Michael Cysouw. 2012. Lexical typology through similarity semantics: Toward a semantic map of motion verbs. Linguistics 50.3, 671-710.

von WALDENFELs, Ruprecht. 2006. Compiling a parallel corpus of Slavic languages. Text strategies, tools and the question of lemmatization in alignment. In: Bernhard Brehmer, Vladislava Zhdanova \& Rafał Zimny, Hrsg., Beiträge der Europäischen Slavistischen Linguistik (POLYSLAv) 9. München: Sagner, 123-138.

von WALDENFELs, RuPRECHT. 2011. Recent developments in ParaSol: Breadth for depth and xsLT based web concordancing with cwB. In: Daniela Majchráková \& Radovan Garabík, eds., Natural Language Processing, Multilinguality. Proceedings of Slovko 2011, Modra, Slovakia, 20-21 October 2011. Bratislava: Tribun EU, 156-162. VON WALDENFEls, RuPRECHT. 2012. Aspect in the imperative across Slavic-a corpus driven pilot study. In: Atle Grønn \& Anna 
Pazelskaya, eds., The Russian Verb. Oslo Studies in Language 4, 141-154

WIEMER, BJöRn. 2001. Aspektual'nye paradigmy i leksičeskoe značenie russkix i litovskix glagolov. Voprosy jazykoznanija 2001.2, 26-58. 